(C) 2020, The Authors. Published by Elsevier Inc. and Fass Inc. on behalf of the American Dairy Science Association ${ }^{\circledR}$. This is an open access article under the CC BY-NC-ND license (http://creativecommons.org/licenses/by-nc-nd/4.0/).

\title{
Brazilian artisanal cheeses are rich and diverse sources of nonstarter lactic acid bacteria regarding technological, biopreservative, and safety properties-Insights through multivariate analysis
}

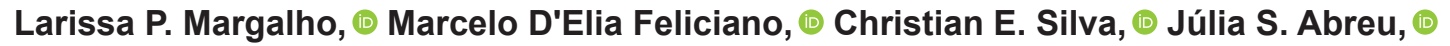 \\ Marcos Vinícius Fiorentini Piran, $(1)$ and Anderson S. Sant'Ana* ${ }^{*}$ \\ Department of Food Science, Faculty of Food Engineering, University of Campinas, Campinas, SP 13083-862, Brazil
}

\begin{abstract}
In this study a total of 220 isolates of lactic acid bacteria (LAB) recovered from 10 types of Brazilian artisanal cheeses marketed in 4 main regions of Brazil were evaluated regarding their safety and ability to produce diacetyl (a precursor of aromatic compounds), exopolysaccharides (EPS; from different sugar sources), and antagonistic activity against Listeria monocytogenes and Staphylococcus aureus. The results indicated that 131 isolates (59.6\%) were classified as strong (40.5\%) and moderate (19.1\%) diacetyl producers; 28 isolates $(12.7 \%)$ stood out due to their remarkable production of EPS from different sugars, including sucrose $(3.2 \%)$, fructose $(2.3 \%)$, lactose $(2.3 \%)$, and glucose $(6 \%)$. Furthermore, $94.1 \%$ and $95.9 \%$ of isolates presented antagonistic activity against $S$. aureus and L. monocytogenes, respectively, even though only 27 isolates $(12.3 \%)$ exhibited positive results in the bacteriocin production test. None of the isolates tested presented hemolytic activity, and 117 were classified as safe, due to their intrinsic resistance to a maximum of 4 different antibiotics. The data obtained for assessment of antibiogram profile and technological potential (moderate and high production of diacetyl, EPS, and bacteriocins) were submitted to a multiple correspondence analysis to correlate them with the cheese of isolation. Regarding the antimicrobial profile of LAB strains, it was possible to verify an association between isolates from Minas artisanal cheeses from Araxá and resistance to tetracycline; Minas artisanal cheeses from Serro and resistance to erythromycin; Coalho and Minas artisanal cheese from Cerrado and resistance to penicillin; and isolates from Serrano and Colonial cheeses with clindamycin and ceftazidime resistance. Although the susceptibility of strains to these antibiotics was considered high (71.8-80.5\%), these data may be related to the horizontal transfer of genes in the production chain
\end{abstract}

Received January 13, 2020.

Accepted May 6, 2020.

*Corresponding author: and@unicamp.br of these cheeses. Results of multiple correspondence analysis also showed that isolates with antagonistic activity were mostly isolated from Manteiga, Colonial, and Coalho cheeses. The isolates with high or moderate EPS-producer ability from sucrose, glucose, and fructose were mainly associated with Minas artisanal cheeses from Cerrado. In contrast, isolates with high or moderate EPS-producer ability from lactose were isolated from Serrano, Minas artisanal cheeses from Canastra, and Campo das Vertentes microregions. Finally, isolates from Minas artisanal cheeses (from Araxá microregion), Coalho, and Caipira cheeses were associated with moderate/high diacetyl production. To the best of the authors' knowledge, this study provides, for the first time, data indicating that the dominant technological, biopreservative, and safety properties of LAB isolates can be correlated with the type of Brazilian artisanal cheeses, which denotes its singularity. This knowledge is of utmost relevance for the development of starter or adjunct cultures with tailored properties.

Key words: multivariate analysis, fermented dairy foods, adjunct cultures, food safety, ripened cheese

\section{INTRODUCTION}

Brazilian artisanal cheeses (BAC) have a relevant historical, socio-economic, and cultural importance for traditional Brazilian communities. Brazilian artisanal cheeses are distinguished by their secular tradition in manufacturing, which is passed from one generation to another, keeping their unique features when compared with industrialized products. Presence of a specific endogenous microbiota in each production region confers cheeses distinct organoleptic characteristics of aroma, flavor, and color, which are much appreciated by the local population and have drawn the attention of researchers and industries since the food product is considered a rich source of microorganisms with a remarkable biotechnological and functional potential to be exploited (Bozoudi et al., 2015; Agostini et al., 2018; Campagnollo et al., 2018b; Kamimura et al., 2019a,b). This biodiversity encompasses yeasts, fungi, 
and mainly lactic acid bacteria (LAB) originated from raw milk and a manufacturing environment (e.g., utensils, food handlers, and insects). Specifically, for artisanal cheeses made in the state of Minas Gerais, the biodiversity also originates from an endogenous culture known as "pingo." Pingo is characterized as a portion of the fermented whey originated from the drainage process of cheeses produced in the previous day and collected in containers to be used as a starter in the production of the following day (de Souza and Dias, 2017; Campagnollo et al., 2018b; Bachtarzi et al., 2019; Kamimura et al., 2019a).

Lactic acid bacteria are widely distributed in nature and can be isolated from several food products of animal and plant origin, and also from the human gastrointestinal tract, which allows them to be recognized as having a generally recognized as safe (GRAS) status. The predominance of this group of bacteria in comparison with others is related to their unique metabolism in fermentative processes. This metabolism involves the synthesis of organic acids (lactic, acetic, and propionic acids) and $\mathrm{pH}$ reduction, production of antimicrobial compounds (such as bacteriocins, hydrogen peroxide, diacetyl, $\mathrm{CO}_{2}$, and so on), and leading to inhibition of undesirable microorganisms in foods, acting as biopreservative agents. In addition to its antimicrobial potential, diacetyl (2,3-butanedione) also plays a key role in the development of distinctive buttery flavor notes in foods, is naturally found in cheeses, butter, and dairy products (Li et al., 2009; Joković et al., 2014). This compound is synthesized by LAB metabolism of citrate (e.g., Lactobacillus, Streptococcus, Lactococcus, and Bacillus) utilizing glucose, lactose, and other carbon sources as substrates (Rincon-Delgadillo et al., 2012). Taking into account that food aroma is an important attribute in food acceptability, many industries and researchers have been seeking for new sources of LAB able to produce such volatile compounds and apply them as starter ingredients in dairy foods (Rincon-Delgadillo et al., 2012; Clark and Winter, 2015).

Furthermore, some LAB species, known as nonstarter lactic acid bacteria, also play a fundamental role in the development of aroma and texture during the ripening process of cheeses, contributing to their quality and identity patterns (Kamimura et al., 2019b; Cuffia et al., 2020). These characteristics include their proteolytic and lipolytic systems, in addition to their production of exopolysaccharides (EPS) as a defense mechanism under stressful conditions, protecting these microorganisms against desiccation and bacteriophage attack (Giraffa, 2012; Bintsis, 2018; Pereira et al., 2019). Exopolysaccharides produced by LAB are essential due to their ability to form highly viscous solutions, even at low concentrations, and their pseudoplastic nature, contributing to texture and rheology of foods, which are attributes much appreciated by consumers. In cheeses, EPS links water molecules present in the complex structure of the casein network, interacting with proteins and micelles found in milk, strengthening the structure of milk curd, and reducing syneresis during the first step of acidification and coagulation present in the cheese-manufacturing process. According to sugar composition, EPS can be divided into homopolysaccharides and heteropolysaccharides. Homopolysaccharides are composed of only one type of monosaccharide, whereas heteropolysaccharides are composed of 2 to 8 repeated types of monosaccharides. Thus, in addition to rheological attributes, EPS produced by LAB can be used as sources of oligosaccharides and sugar monomers, prebiotics, nutraceuticals, sweeteners, and humectants, among others (Duboc and Mollet, 2001; Sanalibaba and Cakmak, 2016).

Studies regarding isolation of autochthonous LAB and their further application as starter or adjunct cultures in the production of cheeses have intensified in recent years and aimed to reproduce peculiar sensorial features of traditional cheeses in a safer manner, contributing to their recognition in terms of geographic location. Moreover, the use of LAB in foods as biopreservative agents by bacteriocin production has become an essential trend due to their higher efficacy in comparison with artificial preservatives, which helps to extend shelf life and to suppress the growth of pathogens in dairy products. Bacteriocins, by definition, are generally low molecular weight proteins or protein complexes, which are synthesized by bacterial ribosomes and are active against genetically closely related microorganisms. Their inhibitory activity is related to pore formation in the bacterial membrane, DNA degradation, and inhibition of peptidoglycan synthesis, among others (De Pasquale et al., 2019; Pereira et al., 2019; Skariyachan and Govindarajan, 2019; Todorov, 2019).

Despite their GRAS status and all associated benefits, some food-grade LAB belonging to Lactobacillus, Lactococcus, and Bifidobacterium genera have been involved in some rare nosocomial infections (e.g., sepsis, bacteremia, endocarditis) in immunocompromised patients, mostly due to their displacement from the gut lumen to blood (Peivasteh-Roudsari et al., 2019; Pradhan et al., 2020). Even if this infection rate is less than $0.5 \%$ (Peivasteh-Roudsari et al., 2019), it is of great concern to evaluate the safe use of new strains, especially wild LAB, which has no history of safe use, before introducing them into the food chain. There is still no consensus by regulatory bodies regarding the criteria used to assess the safety of microorganisms to be applied in food, whether as starters or as probiotics (Pradhan et al., 2020). Nevertheless, among these 
criteria, antibiotic resistance and hemolytic activity are of great concern, as they are associated with the ability to transfer antibiotic resistance genes to other bacteria (including pathogens) and the ability to lyse red blood cell, thus affecting the immune system of the host, respectively. These 2 features represent a risk to public health (Ambalam et al., 2013; Colombo et al., 2018). The indiscriminate use of antibiotics in human and veterinary medicine has increased the number of resistant microorganisms, making the treatment of microbial infections increasingly challenging.

Thus, this study aimed to evaluate EPS production from different sugar sources (lactose, sucrose, fructose, and glucose), diacetyl formation as a precursor of aromatic compounds, and bacteriocinogenic activity of 220 autochthonous Lactobacillus sp. isolates. The strains were obtained from $\mathrm{BAC}$ marketed in 4 main regions of the country to assess their biotechnological and biopreservative potential for application in healthier foods, which will also exhibit geographical features, by use of a multivariate analysis. The microorganisms' susceptibility to antibiotics and the presence of hemolysins were also evaluated to guarantee the safety of possibly new dairy fermented products for human consumption.

\section{MATERIALS AND METHODS}

\section{$L A B$ Isolates}

A total of $220 \mathrm{LAB}$ isolates were obtained from BAC, including samples of Minas artisanal cheeses from Araxá $(\mathrm{n}=16)$, Campo das Vertentes $(\mathrm{n}=36)$, Canastra $(\mathrm{n}=22)$, Cerrado $(\mathrm{n}=2)$, and Serro $(\mathrm{n}=$ 23) microregions of Southeast region; Coalho $(\mathrm{n}=53)$ and Manteiga $(\mathrm{n}=8)$, from Northeast region; Caipira $(\mathrm{n}=39)$, from Center-West region; and Colonial (n $=12)$ and Serrano $(\mathrm{n}=9)$, from South region. These isolates were chosen from a total of 1,002 LAB analyzed in a previous study (Margalho, 2020), due to their high performance in technological tests: extracellular lipolytic and proteolytic enzyme production (Sahraoui et al., 2015), growth in the presence of $\mathrm{NaCl}$, bile salts, and low $\mathrm{pH}$ values (Guo et al., 2010). The identification of strains was performed using the MALDI-TOF MS Biotyper (Bruker Daltonik GmbH, Bremen, Germany), according to Klūga et al. (2017). All isolates were kept frozen $\left(-80^{\circ} \mathrm{C}\right)$ in de Man, Rogosa, and Sharpe (MRS) broth (Merck, Darmstadt, Germany) added with $20 \%$ (vol/vol) of glycerol (Sigma, St. Louis, MO).

\section{Biotechnological Properties}

Diacetyl Production. Evaluation of aromatic compound production (particularly for diacetyl) by LAB was carried out according to King (1948). Thus, LAB isolates from frozen stocks were inoculated $(1 \%)$ in MRS broth (Merck, Darmstadt, Germany) and subcultured twice during $16 \mathrm{~h}$ at $30^{\circ} \mathrm{C}\left(\sim 10^{8} \mathrm{cfu} / \mathrm{mL}\right)$ to guarantee actively growing cells. After growth, they were centrifuged (Sorvall Legend XTR, Thermo Scientific, Germany) at $4,000 \times g$ and $5^{\circ} \mathrm{C}$ for 15 min. Pellets obtained were resuspended in peptone water, inoculated $\left(\sim 10^{6} \mathrm{cfu} / \mathrm{mL}\right)$ in $10 \mathrm{~mL}$ of UHT whole milk $(1 \%, \mathrm{vol} /$ vol), and incubated at $30^{\circ} \mathrm{C}$ for $24 \mathrm{~h}$. Following this, 1 $\mathrm{mL}$ of microbial culture was added with $0.5 \mathrm{~mL}$ of $1 \%$ (wt/vol) $\alpha$-naphthol solution plus $0.5 \mathrm{~mL}$ of $16 \%$ (wt/ vol) sodium hydroxide solution and incubated at $37^{\circ} \mathrm{C}$ for $10 \mathrm{~min}$. Diacetyl production was indicated by the formation of a pinkish ring in tubes and classified as weak, medium, or strong according to intensity of ring color developed based on the modified colorimetric test of Voges-Proskauer (King, 1948).

EPS Production. The EPS evaluation was performed according to Jaouani et al. (2015). The LAB isolates were grown overnight in MRS broth and then streaked on the surface of plates containing modified MRS agar, which was added (5\%, wt/vol) with the following carbon sources: glucose, sucrose, fructose, and lactose, separately. Incubation was carried out at $30^{\circ} \mathrm{C}$ for 48 to $72 \mathrm{~h}$ and isolates that produced slimy and ropy colonies (assessed by touching the colony with an inoculation loop) were considered positive for EPS production and then classified in terms of maximum filament stretching of polymer produced by LAB in high (>5 mm), moderate $(2-5 \mathrm{~mm})$, and weak $(<2 \mathrm{~mm})$ EPS producers.

Antagonistic Activity and Assessment of Bacteriocin-Like Substances. The antagonistic activity was determined, according to Harris et al. (1989), by the use of the well-diffusion assay. According to this assay, a halo of inhibition is observed around LAB colonies, indicating that pathogen growth was suppressed. For this test, $5 \mu \mathrm{L}$ of LAB cultures previously grown overnight in MRS broth was added to the surface of plates containing MRS agar and incubated at $30^{\circ} \mathrm{C}$ for $18 \mathrm{~h}$. Next, $10 \mathrm{~mL}$ of semi-solid brain heart infusion (BHI; $0.85 \%$ agar, wt $/ \mathrm{wt}$ ) containing $10^{6} \mathrm{cfu} / \mathrm{mL}$ of the target pathogen was poured on top of plates and incubated at $37^{\circ} \mathrm{C}$ for $24 \mathrm{~h}$. Pathogenic Staphylococcus aureus ATCC 19095 and Listeria monocytogenes ATCC 7644 were used for this initial screening.

For evaluation of bacteriocin(s) production, LAB isolates presenting antilisterial and antistaphylococcal activity were grown in MRS broth at $30^{\circ} \mathrm{C}$ for $24 \mathrm{~h}$ and centrifuged at $4,000 \times g$ and $4^{\circ} \mathrm{C}$ for 15 min (Sorvall Legend XTR, Thermo Scientific, Berlin, Germany). Cell-free supernatant (CFS) was collected, and $\mathrm{pH}$ adjusted to 6 to 6.5 using $1 \mathrm{~N} \mathrm{NaOH}$. Following this, 
CFS was thermally treated $\left(70^{\circ} \mathrm{C}\right.$ for $\left.30 \mathrm{~min}\right)$ and filtersterilized using $0.22-\mu \mathrm{m}$ membranes. Antilisterial and antistaphylococcal activity of supernatant was evaluated using the spot-on-the-lawn method with modifications (van Reenen et al., 1998). Thus, $10-\mu \mathrm{L}$ aliquots from CFS were placed on the surface of plates containing $10 \mathrm{~mL}$ of bacteriological agar $(1.5 \%$, wt/vol) and covered with an overlay consisting of $5 \mathrm{~mL}$ of semi-solid BHI added with $10^{6} \mathrm{cfu} / \mathrm{mL}$ of the target pathogen. Plates were incubated at $37^{\circ} \mathrm{C}$ for $24 \mathrm{~h}$ and observed for halo formation. Confirmation of bacteriocin production was carried out by evaluation of the proteinaceous nature of the antimicrobial compound. For this test, CFS was treated $\left(1 \mathrm{~h}\right.$ at $\left.37^{\circ} \mathrm{C}\right)$ with the following proteolytic enzymes: $\alpha$-chymotrypsin type II from bovine pancreas, protease type XIV from Streptomyces griseus, trypsin, and proteinase K (all purchased from SigmaAldrich, St. Louis, MO) solubilized in $20 \mathrm{mM}$ (pH 7.0) phosphate buffer. After treatment, CFS was heated at $90^{\circ} \mathrm{C}$ for 5 min to inactivate enzymes and tested by the spot-on-the-lawn method as described above to assess residual antimicrobial activity against $S$. aureus and $L$. monocytogenes strains. The absence of halo formation after the performance of enzymatic treatment indicated the presence of bacteriocins. The following foodborne pathogens were tested in the bacteriocin test: enterotoxin-producing $S$. aureus FRI S6, S. aureus FRI 361, L. monocytogenes ATCC 3968 (serotype $1 / 2 \mathrm{~b}$ ), and $L$. monocytogenes ATCC 3973 (serotype 4b). All strains were kindly donated by Oswaldo Cruz Foundation (Rio de Janeiro, RJ, Brazil). Each strain was separately grown in $\mathrm{BHI}$ broth at $37^{\circ} \mathrm{C}$ for $24 \mathrm{~h}$, centrifuged $(4,000$ $\times g ; 4^{\circ} \mathrm{C} ; 15 \mathrm{~min}$ ), and washed 2 times in PBS (Merck, Darmstadt, Germany). The concentration of cells in the suspensions was adjusted to $0.5 \mathrm{McFarland}\left(\sim 10^{8}\right.$ $\mathrm{cfu} / \mathrm{mL}$ ) and diluted $100 \times$ to have a final concentration of $10^{6} \mathrm{cfu} / \mathrm{mL}$ for the tests.

\section{Safety Evaluation}

Antibiogram. Antibiogram analysis was performed in duplicates, with 3 replicates each, according to the antimicrobial susceptibility disk diffusion method with modifications (Charteris et al., 1998). The LAB isolates were previously cultivated in MRS broth. Bacterial cells were collected and washed in PBS. Pellet was transferred to tubes containing $3.5 \mathrm{~mL}$ of sterilized saline solution $(\mathrm{NaCl} 0.85 \%$, wt/vol) to reach 0.5 in the McFarland scale $\left(10^{8} \mathrm{cfu} / \mathrm{mL}\right)$. Then, sterilized swabs were used to inoculate the microorganisms on top of plates containing MRS agar. Afterward, disks (all purchased from Cecon, São Paulo, SP, Brazil) containing the antimicrobials ceftazidime $(30 \mu \mathrm{g})$, clindamycin $(2 \mu \mathrm{g})$, ciprofloxacin $(5 \mu \mathrm{g})$, erythromycin $(5 \mu \mathrm{g})$, gentamicin
$(10 \mu \mathrm{g})$, oxacillin $(1 \mu \mathrm{g})$, penicillin $(10 \mathrm{U})$, streptomycin $(30 \mu \mathrm{g})$, tetracycline $(30 \mu \mathrm{g})$, and vancomycin $(30 \mu \mathrm{g})$ were placed on surface plates, which were then incubated at $37^{\circ} \mathrm{C}$ for $24 \mathrm{~h}$. As a quality control for disks, Escherichia coli ATCC 25922 was used. Diameters of inhibition halos were measured, and microorganisms were qualitatively classified as sensitive, moderately sensitive, or resistant against antimicrobials tested, according to the recommendation of the Clinical and Laboratory Standards Institute (CLSI, 2012).

Hemolysis. For evaluation of hemolytic activity, LAB isolates $(\mathrm{n}=220)$ were grown overnight in MRS broth, inoculated onto blood agar (sheep blood added at $7 \%, \mathrm{vol} / \mathrm{vol}$ ), and incubated at $37^{\circ} \mathrm{C}$ for $48 \mathrm{~h}$, following manufacturer's instructions (Labcenter, Campinas, Brazil). Isolates that exhibited greenish halos around colonies ( $\alpha$-hemolysis) or produced no inhibition halo ( $\gamma$-hemolysis) were classified as nonhemolytic. Alternatively, isolates that produced bright halos around colonies ( $\beta$-hemolysis) were classified as hemolytic.

\section{Statistical Analyses}

Semi-qualitative data obtained for biotechnological potential (production of EPS, diacetyl, and bacteriocins) and safety evaluation (antibiogram and hemolytic activity) were analyzed using multiple correspondence analysis (MCA) and software PAST v. 3.26 (Hammer et al., 2001) to assess the effect of cheese type/region of isolation on the performance of LAB. Isolates that were sensitive to less than 4 antibiotics tested were selected for principal component analysis (PCA) using Pirouette 3.11 software (Infometrix, Bothell, WA) to select the groups with the best (most promising) results for use in foods. Data obtained were converted into codes $(3,2,1$, and 0 for high, moderate, weak, and nonproducers of EPS, diacetyl, and bacteriocin, respectively) and used as input data.

\section{RESULTS}

\section{Isolation and Identification of $L A B$}

Among 220 LAB isolates that presented good technological potential [reported in a previous study performed by our research group (unpublished data)], only 179 were identified at the species level, and 41 were classified as belonging to Lactobacillus genus (as described in Supplemental Table S1, https://doi.org/10 $.3168 /$ jds.2020-18194). Figure 1 shows the total number of LAB isolates, their identification at the species level, and distribution per type of cheese/region.

As shown in Figure 1, Lactobacillus plantarum was the most frequently isolated species from artisanal 
cheeses evaluated (47.7\%), followed by Lactobacillus brevis (16.4\%), Lactobacillus paracasei (9.1\%), Lactococcus lactis (2.7\%), Lactobacillus rhamnosus (2.3\%), Pediococcus pentosaceus (0.9\%), Lactobacillus curvatus (0.5\%), Lactobacillus paraplantarum (0.5\%), Lactococcus garvieae (0.5\%), and Pediococcus acidilactici $(0.5 \%)$. As for highlights, Minas artisanal cheeses from Canastra exhibited 7 out of $10 \mathrm{LAB}$ species detected in the study, whereas Caipira and Colonial cheeses were the only ones to harbor $L b$. curvatus and Pd. acidilactici, respectively. Most of the isolates belonged to the Southeast region and were obtained from Minas artisanal type cheese (45.0\%), being distributed per microregion as follows: Serro $(n=23)$, Cerrado $(n=2)$, Canastra $(\mathrm{n}=22)$, Campo das Vertentes $(\mathrm{n}=36)$, and Araxá $(\mathrm{n}=16)$. Moreover, isolates presenting the best technological potential were obtained from Northeast region $(27.73 \%)$ : Coalho $(\mathrm{n}=45)$, Coalho light $(\mathrm{n}=9)$, and Manteiga $(\mathrm{n}=7)$ cheeses; and from Center-West and Southeast regions, accounting for $17.7 \%$ and $9.6 \%$ of isolates belonging to Caipira $(\mathrm{n}=39)$, Colonial $(\mathrm{n}=$ $12)$, and Serrano $(n=9)$ cheeses, respectively.

\section{Technological and Biopreservative Potential}

Lipolytic and proteolytic LAB were also able to grow in modified MRS broth with $\mathrm{NaCl}$ (4 and 6\%), con- tributing to the technological process of cheese production. Therefore, these strains were chosen for further analyses, for a more in-depth characterization of their technological and biopreservative potential. A total of 220 LAB isolates were evaluated for their inhibitory activity against $L$. monocytogenes and $S$. aureus strains and the production of diacetyl, EPS, and bacteriocins. Figure 2 shows the main results obtained for diacetyl production, expressed as high $(+++)$, moderate $(++)$, or weak $(+)$. For bacteriocin detection, no inhibition halos were observed after the heat treatment of CFS and the addition of proteolytic enzymes, which indicated the proteinaceous nature of the inhibitory substance.

Table 1 summarizes data obtained for the tests mentioned above, considering all species of LAB determined in this study. According to our results, 131 isolates $(59.6 \%)$ were classified as strong $(40.5 \%)$ and moderate (19.1\%) diacetyl producers. Also, 28 isolates $(12.73 \%)$ stood out as high EPS producers from sugar sources: sucrose $(3.2 \%)$, fructose $(2.3 \%)$, lactose $(2.3 \%)$, and glucose $(6 \%)$. Moreover, $94.1 \%$ and $95.9 \%$ of the LAB isolates presented inhibitory activity against pathogenic $S$. aureus and L. monocytogenes, respectively; however, only $27 \mathrm{LAB}$ isolates $(12.27 \%)$ exhibited positive results in the test performed for bacteriocin production, confirming the proteinaceous origin of the antimicrobial substance.

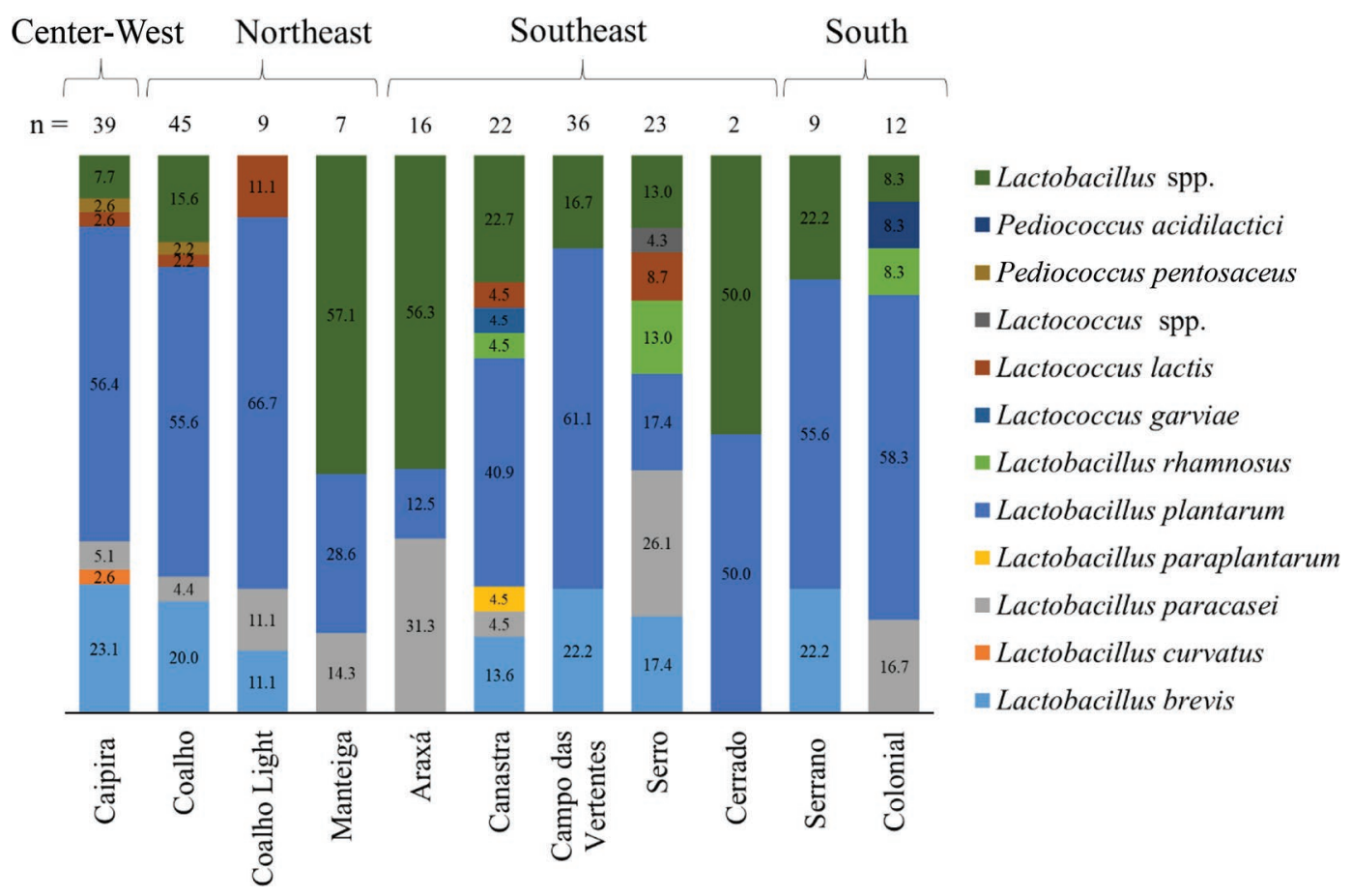

Figure 1. Lactic acid bacteria diversity determined in different types of Brazilian artisanal cheeses: Caipira, Coalho, Coalho Light, Manteiga, Minas artisanal (from Araxá, Canastra, Campo das Vertentes, Serro, and Cerrado microregions), Serrano and Colonial, obtained from 4 main regions (Center-West, Northeast, Southeast, and South) of the country and expressed as number (n) of isolates and respective percentages (\%) for each species determined presenting technological potential. 
Most of the isolates belonging to Lb. rhamnosus (80.0\%), Lb. brevis $(72.2 \%)$, and Lb. paracasei $(65 \%)$ species stood out for showing moderate to high diace- tyl formation. Same isolates of Lb. rhamnosus (80.0\%) were also good to moderate EPS producers from sucrose. Despite its weak ability to form diacetyl, isolate

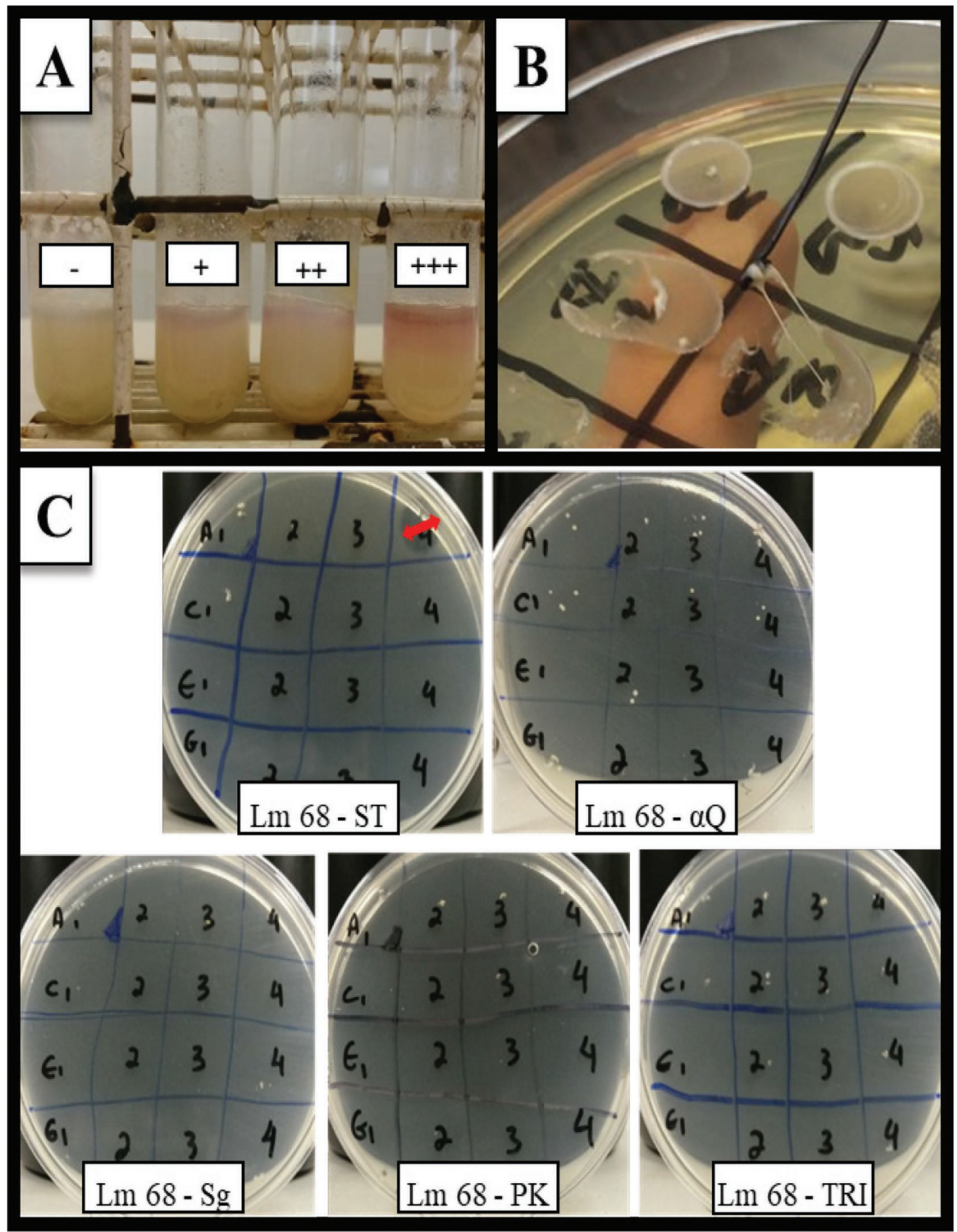

Figure 2. (A) Analysis of diacetyl formation by lactic acid bacteria (LAB) isolates, expressed as high $(+++)$, medium $(++)$, weak $(+)$, and no production (-), as shown from left to right tubes, according to intensity of pinkish ring observed; (B) evaluation of exopolysaccharide production by LAB isolates presenting slimy and mucoid colonies and classified as high $(+++)$, indicating a maximum filament stretching of polymer produced $(>5 \mathrm{~mm})$; and $(\mathrm{C})$ positive result for bacteriocin production. Halo initially observed in ST [standard treatment: no enzymes added to cell-free supernatant (CFS)] plate indicating Listeria monocytogenes 68 (Lm 68) inhibition, which was no longer observed after treatment of CFS with proteolytic enzymes $\alpha$-chymotrypsin type II from bovine pancreas $(\alpha \mathrm{Q})$, protease type XIV from Streptomyces griseus (Sg), trypsin (TRI), and proteinase K (PK), corroborating the proteic nature of the compound(s) synthesized by LAB isolate. Each quadrant (A1, C1, E1, G1, 2, 3, and 4) represents a different microorganism tested. 
2QB481 (Lc. garvieae) was considered a good producer of EPS from all tested carbon sources; and isolate 1QB399 ( $L b$. paraplantarum) as a good EPS producer from fructose and lactose. Both strains (2QB481 and 1QB399) were recovered from Minas artisanal cheeses of Canastra microregion. Lactococcus lactis (28.6\%) and Lb. plantarum (13.3\%) comprised the most significant numbers of bacteriocin-producing isolates. Strains of $P d$. acidilactici (2QB502), Pd. pentosaceus (2QB101 and 1QB416), and Lb. curvatus (2QB417) presented weak diacetyl formation and weak or no EPS production from sucrose, fructose, and lactose. Results obtained for bacteriocin analysis, including information regarding identification and origin (cheese type, city, region, and microregion for artisanal Minas cheese) of LAB isolates are shown in Table 2. The proteinaceous nature of the inhibitory substance(s) produced by LAB isolates against pathogens was confirmed when nontreated CFS led to the formation of inhibition halos, and CFS treated with proteolytic enzymes resulted in no inhibition halos. Overall, $27 \mathrm{LAB}$ isolates were characterized as bacteriocin producers. In Figure 2, halo formation was indicated by a positive symbol $(+)$, and the absence of inhibition halos was demonstrated by a negative symbol $(-)$.

According to our results, among this group of bacteriocinogenic strains (Table 2), only one isolate (1QB314) was able to inhibit the growth of all pathogens tested. Five isolates (2QB502, 1QB77, 3QB167, 1QB167, 1QB459) inhibited both strains of L. monocytogenes tested and $S$. aureus FRI S6. One isolate (2QB422) was able to inhibit both strains of $L$. monocytogenes. Isolate 2QB383 inhibited L. monocytogenes ATCC 3968 and S. aureus FRI S6. Three isolates (1QB352, 1QB371, and 1QB98) were only able to inhibit $L$. monocytogenes ATCC 3968, whereas 11 isolates (1QB147, 2QB77, 1QB113, 1QB128, 2QB147, 1QB127, 3QB361, 2QB81, 1QB117, 3QB350, and 3QB398) were merely able to inhibit L. monocytogenes ATCC 3973. Isolate 3QB216 only inhibited $S$. aureus FRI S6, whereas 4 isolates (1QB52, 2QB446, 2QB350, and 3QB497) merely inhibited $S$. aureus FRI 361. Most of the isolates were obtained from Minas artisanal cheeses $(\mathrm{n}=11)$ from different microregions: Serro $(\mathrm{n}=5)$, Campo das Vertentes $(\mathrm{n}=4)$, Araxá $(\mathrm{n}=1)$, and Canastra $(\mathrm{n}=1)$, followed by Coalho $(\mathrm{n}=6)$, Caipira $(\mathrm{n}=5)$, Colonial $(\mathrm{n}=3)$, and Manteiga $(\mathrm{n}=2)$ cheeses and were identified as $L b$. brevis $(\mathrm{n}=3), L b$. paracasei $(\mathrm{n}=1), L b$. plantarum $(\mathrm{n}=15)$, Lc. lactis $(\mathrm{n}=2)$, Pd. acidilactici $(\mathrm{n}=1)$, and Lactobacillus sp. $(\mathrm{n}=5)$. Data obtained for assessment of technological potential (moderate and high production of diacetyl, EPS, and bacteriocins) were submitted to a MCA to possibly correlate them with the source of LAB isolation (cheese type), as shown in Figure 3.

According to outputs obtained from MCA, the first and the second dimension comprised $58.9 \%$ and $23.2 \%$, respectively, and explained $82.1 \%$ of the total variance observed in the data set. Moreover, variables tested were significantly different $(P<0.05)$ among each other. A cluster of isolates from Manteiga, Colonial, and Coalho cheeses was observed around variable B (bacteriocin production). Isolates obtained from Minas artisanal (from Cerrado microregion) cheeses were clustered around variables S, F, and G, indicating high or moderate EPS production from sucrose, fructose, and glucose. Furthermore, isolates from Serrano and Minas artisanal cheeses from Canastra and Campo das Vertentes microregions were clustered around variable $\mathrm{L}$, indicating high or moderate EPS production from lactose. Finally, isolates from Minas artisanal (from Araxá microregion), Coalho, and Caipira cheeses were clustered around variable D (moderate or high diacetyl production).

\section{Safety Evaluation}

In addition to data obtained for assessment of technological potential, further tests were performed to determine the presence of virulence factors in LAB isolates. Table 3 shows the results obtained for the antibiogram test using antimicrobial agents recommended by CLSI (2012). According to our data, most of the LAB isolates were resistant to ciprofloxacin $(81.4 \%)$, gentamicin (94.6\%), and vancomycin (97.3\%) and all LAB isolates were resistant to streptomycin. In contrast, most of LAB isolates were sensitive to tetracycline (95.0\%), erythromycin $(93.2 \%)$, ceftazidime $(80.5 \%)$, penicillin (76.4\%), and clindamycin (71.8\%). Furthermore, $40.9 \%$ of isolates were resistant to oxacillin, whereas $45.5 \%$ of them were resistant to the antibiotic.

Figure 4 shows the overall profile of antibiotic susceptibility obtained for LAB isolates. Results are expressed in terms of LAB species and resistance against 2 to 4,5 to 7 , and 8 to 10 antibiotics. Most of the isolates $(53.2 \%)$ were resistant to less than 5 antibiotics, $43.2 \%$ to 5 to 7 antibiotics, and $3.6 \%$ to more than 8 antibiotics. Notably, only 3 isolates identified as Lc. lactis, one isolate corresponding to $L b$. plantarum, and 4 isolates determined as $L b$. brevis were resistant to more than 8 antibiotics. In the present study, only isolates that were resistant to less than 4 antibiotics were chosen for further analyses. Figure 5 shows the results obtained for correspondence analysis between LAB isolates considered resistant to the antibiotics (according to the antibiogram results) and their source of isolation. An 


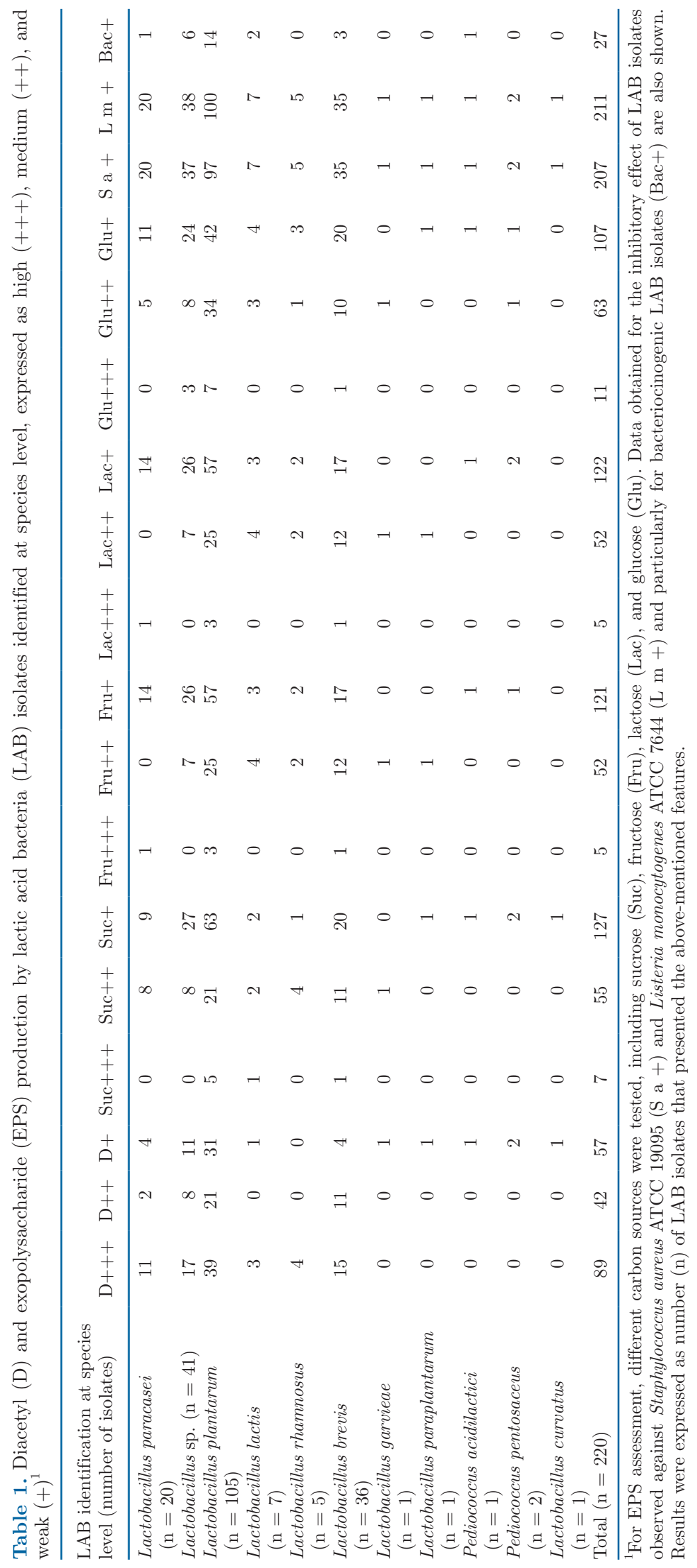


Margalho et al.: MULTIVARIATE ANALYSIS OF BRAZILIAN ARTISANAL CHEESES

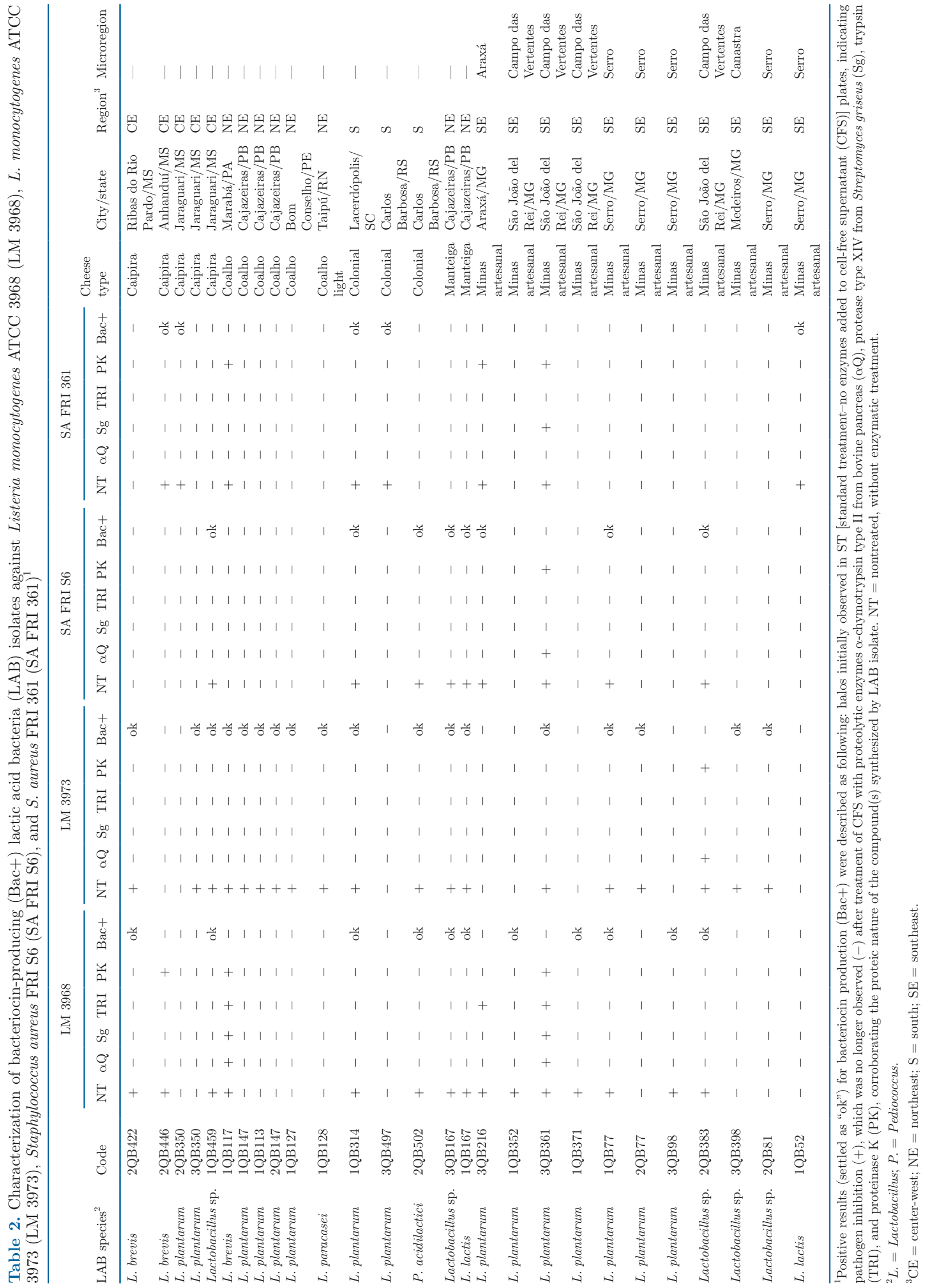




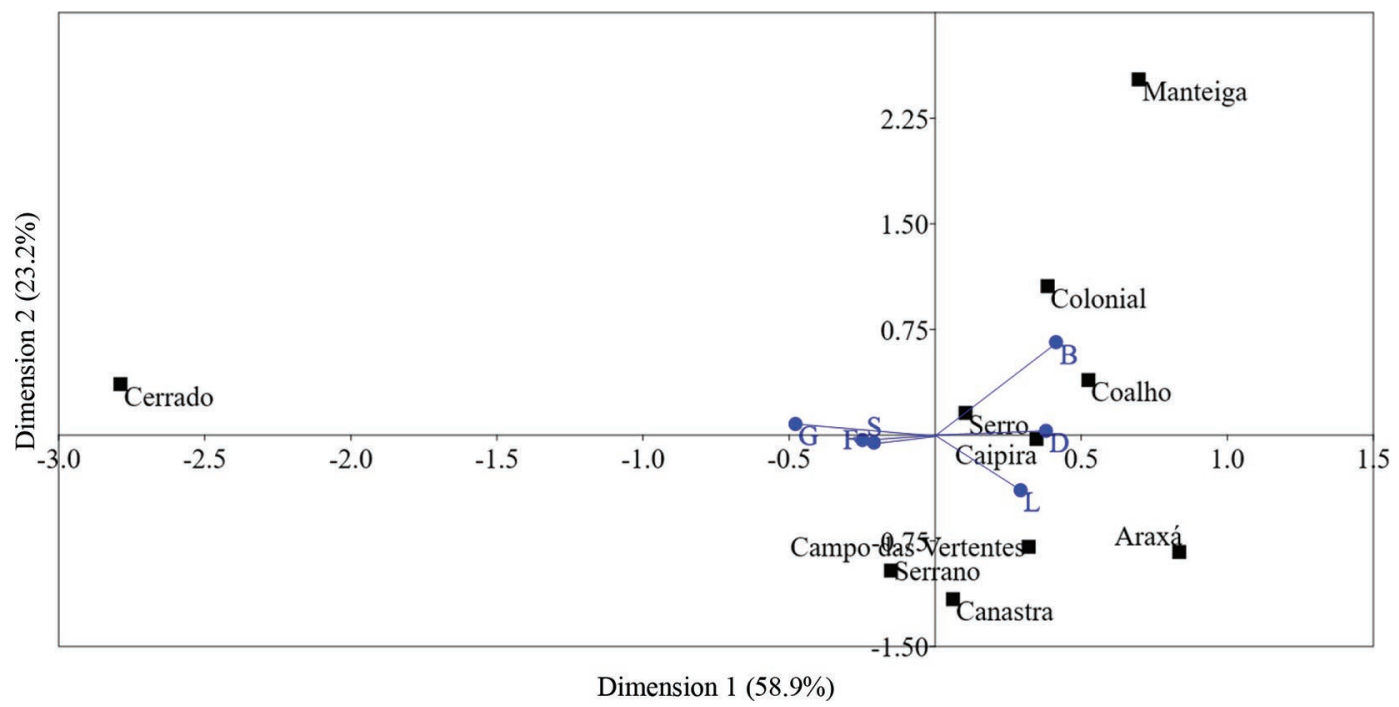

Figure 3. Correspondence analysis map determined for lactic acid bacteria (LAB) isolated from Brazilian artisanal cheeses: Caipira, Coalho, Colonial, Manteiga, Minas artisanal (from Araxá, Campo das Vertentes, Canastra, Cerrado, and Serro microregions), and Serrano (represented by solid black squares). All cheeses were obtained from the 4 main regions of Brazil and their LAB features (represented by solid blue circles) were classified as moderate $(++)$ or high $(+++)$ diacetyl $(\mathrm{D})$ and exopolysaccharide from fructose $(\mathrm{F})$, lactose $(\mathrm{L})$, sucrose $(\mathrm{S})$, and glucose $(\mathrm{G})$ producers; and also as positive (+) for bacteriocin (B) activity.

association between Coalho (added with spices) and Minas artisanal (from Cerrado microregion) cheeses and resistance to penicillin was observed.

Moreover, LAB isolates obtained from Minas artisanal (from Araxá microregion) cheese clustered around the TET variable (resistance against tetracycline). On the other hand, LAB isolates from Minas artisanal (from Serro microregion) cheese grouped around the ERY variable, indicating a higher number of microorganisms resistant to erythromycin. Finally, LAB isolates from Serrano and Colonial cheeses clustered around variables CLI and CAZ (resistance against clindamycin and ceftazidime). Also, LAB isolates obtained from Caipira, Minas artisanal (from Canastra and Campo das Vertentes microregions), and Coalho light were grouped around variables OXA and CIP (resistance against oxacillin and ciprofloxacin, respectively). No LAB isolates presented positive results for hemolysis tested performed in blood agar so that all microorganisms were classified as $\gamma$-hemolytic, which is an important safety issue when the application in food formulations is intended.

\section{PCA}

Results obtained from tests performed to assess the technological potential (diacetyl, EPS, and bacteriocin production) of LAB isolates that were shown to be resistant to less than 4 antibiotics $(n=117)$ were then submitted to a PCA, as shown in Figure 6. The first 7 components comprised $95.5 \%$ of the total variance.
Among them, PC1 and PC2 components represented 30.5 and $22.1 \%$ of the total variance, respectively. Three distinct groups of bacteria (namely groups A, B, and C) could be observed, and their significant features are also shown in Figure 6B. As for highlights, group C exhibited high $(+++)$ EPS production from fructose and lactose; group A presented weak EPS production from fructose and lactose; group B encompassed microorganisms that did not produce EPS from both sugar sources but were good diacetyl producers.

A positive correlation between variable high diacetyl formation $(\mathrm{D}+++)$ and weak EPS production from glucose and sucrose was observed, as well as between high EPS production from both sugar sources $(\mathrm{Suc}+++$ and $\mathrm{Glu}+++$ ) and weak diacetyl formation $(\mathrm{D}+)$. The number of bacteriocin-producing LAB isolates was higher in group A $(\mathrm{n}=9)$, followed by group B (n $=4$ ), and interestingly, these groups were shown to present, respectively, weak or no EPS production from lactose and fructose. A significant correlation between type cheese and groups was determined, as follows: group A was positively correlated with Minas artisanal (from Serro microregion) cheeses; group B with Minas artisanal (from Araxá, Campos das Vertentes, and Canastra microregions); and group $\mathrm{C}$ with Serrano and Minas artisanal cheeses from Cerrado microregion. In terms of isolate identity, Lc. lactis, Lb. curvatus, and Lc. garvieae were observed only in groups A, B, and C, respectively.

In contrast, Lb. brevis, Lb. paracasei, Lb. plantarum, and $L b$. rhamnosus were determined in all groups, indi- 


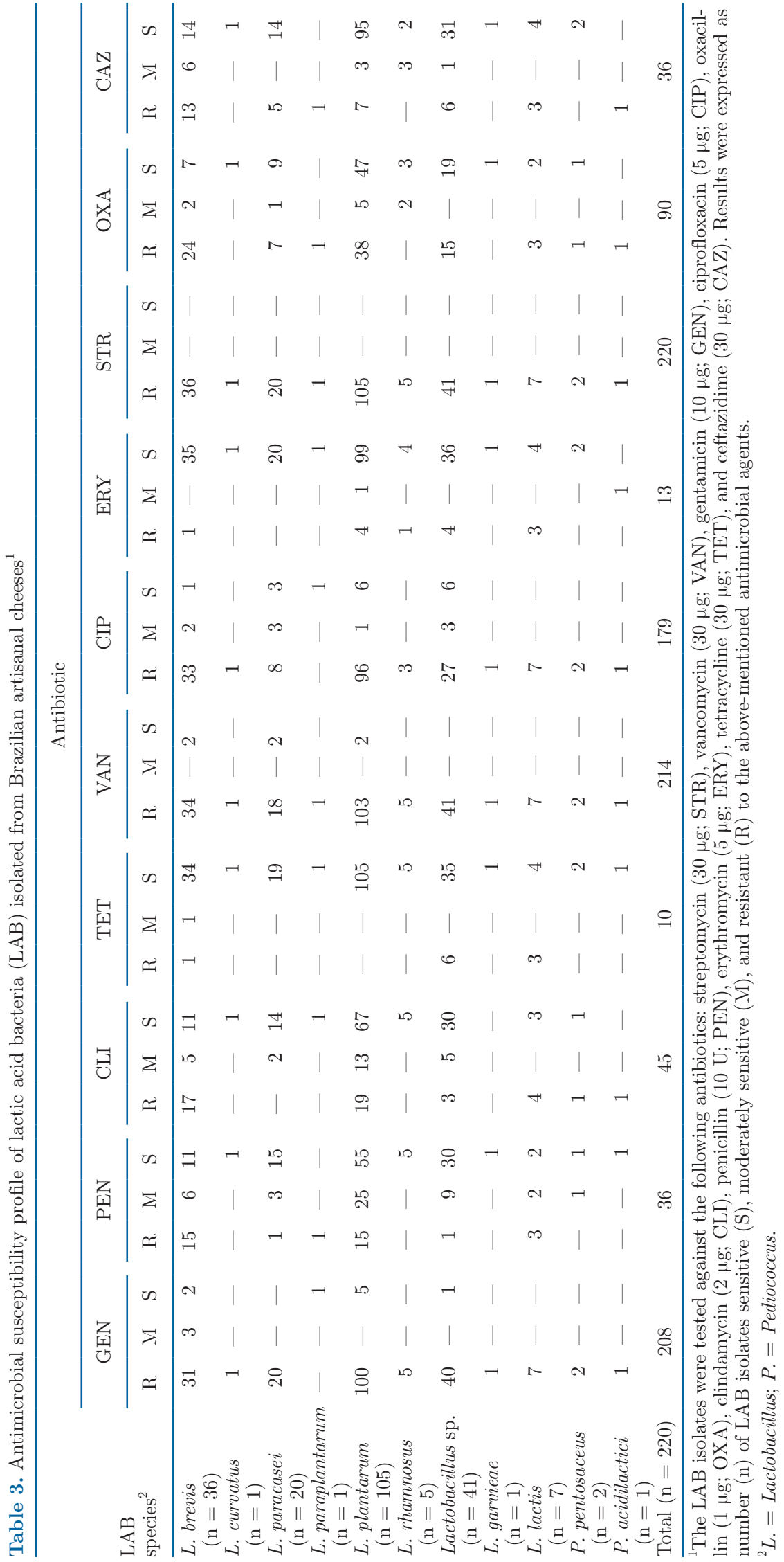


cating their properties vary according to source isolation (geographical region), also suggesting an intraspecies variability depending on cheese type from where they were obtained.

\section{DISCUSSION}

This study aimed to evaluate EPS production from different sugar sources, diacetyl formation in milk, bacteriocinogenic potential, and virulence factors of 220 LAB isolates belonging to genera Lactobacillus, Lactococcus, and Pediococcus, classified as nonstarter lactic acid bacteria in a previous study performed by our research group (unpublished data) due to their intrinsic resistance against salt and low $\mathrm{pH}$ values and ability to produce proteolytic and lipolytic enzymes in the extracellular medium. Lactic acid bacteria diversity in cheeses is related to several factors, such as breed, herd diet type, manufacturing process involving rudimentary techniques and autochthonous microbiota from raw milk, and processing environment, which profoundly contribute to differences found in terms of aroma, color, and flavor observed in artisanal cheeses produced in different regions of Brazil. The Lactobacillus genus has been intensively evaluated for pro-technological characteristics in artisanal Brazilian cheeses (Cabral et al., 2016; Kamimura et al., 2019a,b).

One of the most important features of LAB is their ability to synthesize diacetyl (2,3-butanedione), respon- sible for aroma development in fermented foods, and other molecules (e.g., $\mathrm{CO}_{2}$, aldehyde, acetic acid, and so on) formed from citrate by monophosphate pentose pathway in heterofermentative bacteria. In this study, $131(59.6 \%)$ LAB isolates were able to produce diacetyl from milk lactose, indicating their potential application as adjunct cultures in cheeses production. During cheesemaking, starter bacteria (normally homolactic) reduce milk $\mathrm{pH}$ due to acid, lactic buildup (produced from milk lactose). This first acidification step facilitates citrate transport from milk into LAB cells, using an enzyme known as citrate permease, and the molecule can be the precursor of aromatic compounds, such as diacetyl and aldehyde (de Souza and Dias, 2017). In reality, several studies carried out with LAB isolated from artisanal cheeses have demonstrated diacetyl production (Taboada et al., 2014; de Almeida Júnior et al., 2015; Ferrari et al., 2016; de Souza and Dias, 2017; Agostini et al., 2018). Nonetheless, the current study assessed a great variety of BAC, marketed in 4 main regions of the country, and indicated that Coalho, Caipira, and Minas (from Araxá microregion) cheeses, originating from Northeast, Center-West, and Southeast, were the primary sources of diacetyl-producing isolates (Figure 3).

Another relevant aspect for selection of starter or adjunct cultures is their ability to produce EPS from different sugar sources, acting as emulsifiers, thickeners, stabilizers, or water-binding agents, essential features

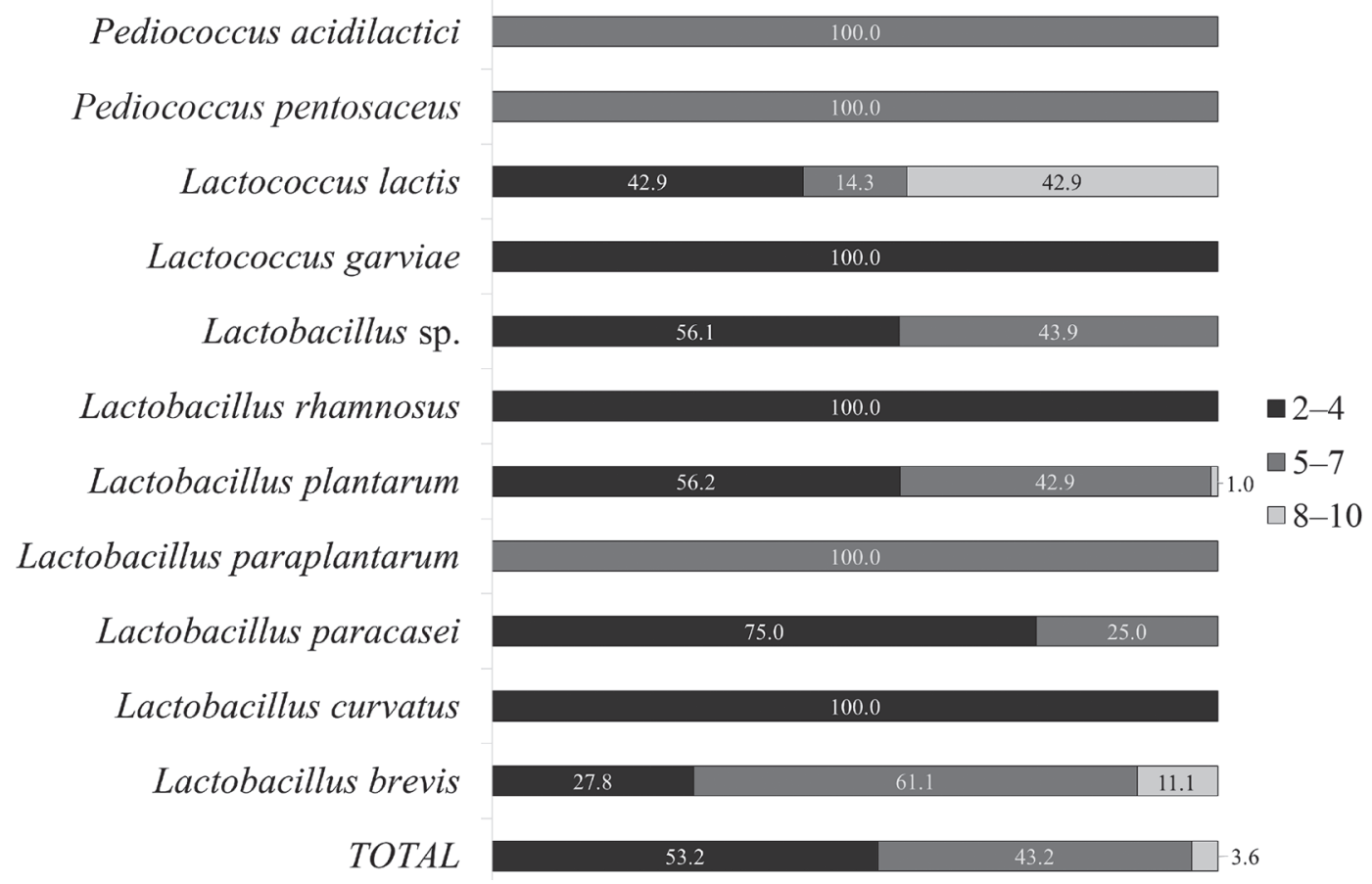

Figure 4. Assessment of prevalence (expressed in percentage) of different species of lactic acid bacteria obtained in the present study resistant to 2 to 4,5 to 7 , or 8 to 10 antibiotics. 
from an industrial point of view, due to an improvement on texture and rheology associated with this phenotype (Sanalibaba and Cakmak, 2016). In the present study, $74(33.6 \%), 64(29.1 \%), 62(28.2 \%)$, and $57(25.9 \%)$ out of $220 \mathrm{LAB}$ strains were able to use glucose, lactose, sucrose, and fructose, respectively, as the primary carbon source for good to high EPS production. This test can be visually observed as the development of slimy colonies (Figure 2). The evaluation of this phenotype is considered the primary screening method for the selection of high EPS-producing strains in bench-scale and relies on inoculation of plates containing appropriate solid culture medium supplemented with sugar sources to be studied. This technique has been widely reported in the literature, and glucose is considered the most efficient carbon source for EPS production, although different sugars can be used, leading to a considerable variability on EPS synthesis and composition (Yuksekdag and Aslim, 2008; Malik et al., 2009; Bennama et al., 2012; Ishola and Adebayo-Tayo, 2012; Paulo et al., 2012; Zeidan et al., 2017; Oleksy and Klewicka, 2018). In our study, the significant prevalence of LAB (66.4\%) exhibiting high EPS production from at least one sugar source indicates BAC can be considered valuable sources of autochthonous strains with the potential to be employed as adjunct cultures in the dairy industry, and as inoculum in the biopolymer industry.

In the case of isolates that showed high or good EPS formation from lactose, they can be used alone or in combination with starter cultures for the production of dairy fermented products, improving rheology and texture, in addition to contributing to their functional properties. A number of studies regarding EPS (+)-producing LAB indicated improvement of aroma, texture, and consistency of cheeses, particularly lowfat cheeses (light), due to retention of water molecules during clot formation, reducing water activity $\left(\mathrm{a}_{\mathrm{w}}\right)$, and consequently, syneresis (Schmid et al., 2015; Zhang et al., 2015; Ayyash et al., 2018; Wang et al., 2018; Berthold-Pluta et al., 2019). The EPS production by these LAB isolates can also represent an alternative to increase efficiency and yield on cheese production, drawing industries attention to cheaper, more natural, and more sustainable biopolymers, which also have regional characteristics, indicating Serrano (South) and Minas artisanal cheeses from Canastra and Campo das Vertentes microregions (Southeast) as the primary sources of EPS $(+)$-producing LAB from lactose (Figure $3)$. In addition to these technological applications, EPS production has been associated with Lactobacillus sp. probiotic potential to be used in the formulation of fermented functional foods. The presence of EPS can increase residence time in host gastrointestinal tract; facilitate colon colonization; exert anticarcinogenic, antiulcer, and antiviral activity; reduce cholesterol levels; and thus, contribute positively to human health (N'tcha et al., 2016; Zannini et al., 2016; Lynch et al., 2018).

On the other hand, the use of microorganisms in the biopolymer industry, especially LAB, has been gaining prominence due to the advantages of controlling and

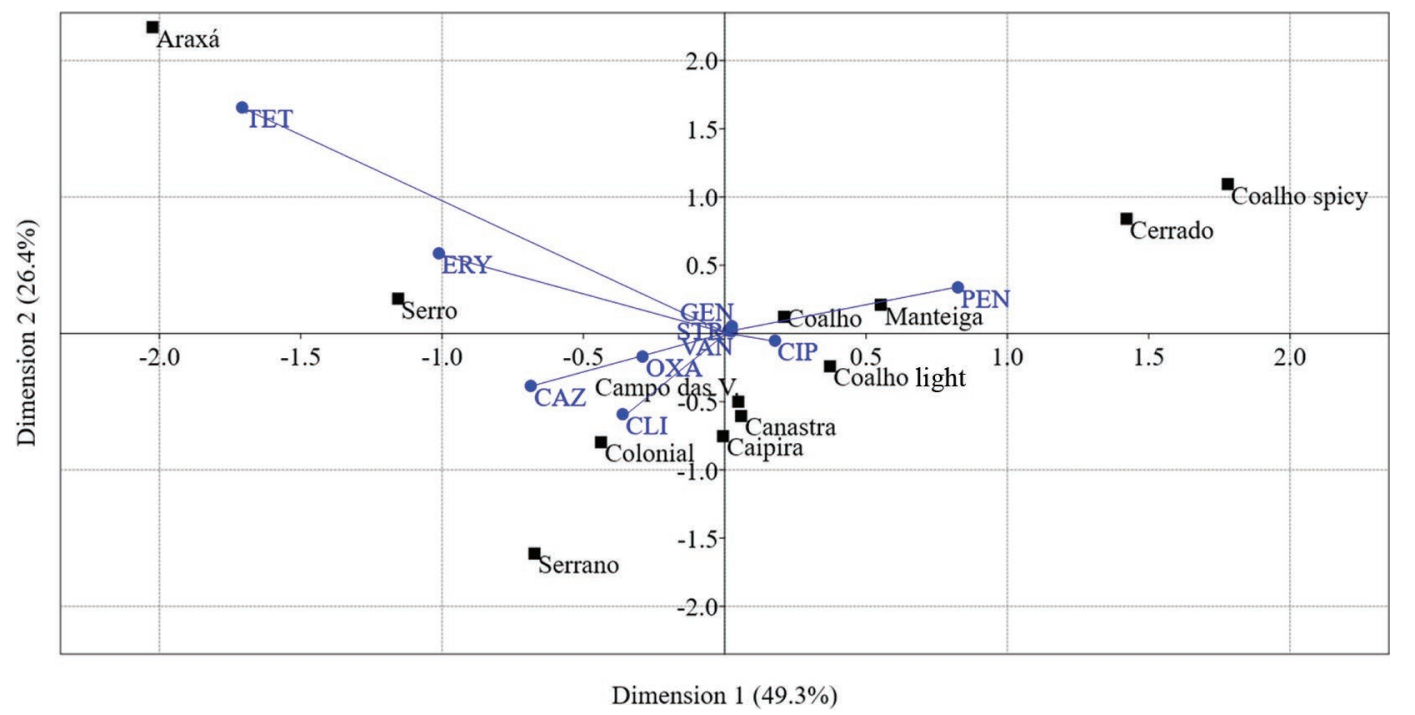

Figure 5. Correspondence analysis map determined for lactic acid bacteria (LAB) isolated from Brazilian artisanal cheeses: Caipira, Coalho, Colonial, Manteiga, Minas artisanal (from Araxá, Campo das Vertentes, Canastra, Cerrado, Serro microregions), and Serrano (represented by solid black squares). All cheeses were obtained from the 4 main regions of the country and their LAB resistance against the following antibiotics (represented by solid blue circles), according to the disk diffusion antimicrobial susceptibility testing method: streptomycin (30 $\mu \mathrm{g}$; STR),

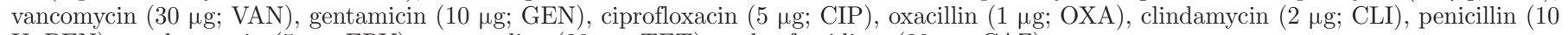
$\mathrm{U} ; \mathrm{PEN})$, erythromycin $(5 \mu \mathrm{g} ; \mathrm{ERY})$, tetracycline (30 $\mu \mathrm{g}$; TET), and ceftazidime (30 $\mu \mathrm{g}$; CAZ). 
optimizing fermentation conditions to increase production yield in a short time (Chaisuwan et al., 2020). This approach represents an advantageous alternative to the current use of biopolymers produced from vegetable matrices and algae, whose production is more difficult to control (Kanimozhi et al., 2018; Barcelos et al., 2020). For this reason, several studies emphasize the importance of diversifying the production of EPS by utilizing different sources of carbon and nitrogen and by adjusting fermentation conditions (e.g., inoculum age, $\mathrm{pH}$, temperature, agitation, $\mathrm{O}_{2}$ ) to optimize the process production via the biotechnological route (Rahbar Saadat et al., 2019; Barcelos et al., 2020). This approach involves the exploration of new species of bacteria and, consequently, the production of new biopolymers with different functions.

Despite the high degree of purity of biopolymers produced by such fermentation processes, the costs associated with microbial production of polymers have attracted the market's attention to the use of cheaper sources of carbon in the composition of the fermentation medium, which currently represents $30 \%$ of the costs associated with the production of EPS (Kanimozhi et al., 2018). Thus, the use of agro-industrial waste as an alternative carbon source has gained prominence, once they are considered as renewable, cheaper, natural, and rich in sugars (fructose, sucrose, and glucose), nitrogen, and vitamins (Kanimozhi et al., 2018). Such organic compounds can be easily assimilated by microorganisms and transformed into biological products. Some of these waste resources include sugarcane molasses, sugarcane juice, coconut water, fruit juice, peels, and pomace of fruits and vegetables (Özcan and Öner, 2015; Kanimozhi et al., 2018; Chaisuwan et al., 2020).

In our study, 74 (33.6\%), $62(28.2 \%)$, and $57(25.9 \%)$ out of the 220 LAB tested showed good potential for the formation of EPS from glucose, sucrose, and fructose, respectively. Most of these microorganisms belong to $L b$. plantarum and $L b$. brevis species. Thus, such strains can be applied in new research involving biotechnological uses of the above-mentioned low-cost substrates in EPS production, mostly in Brazil, whose economy is known to be agriculture based. In addition to contributing cost-effectiveness biopolymer production, the need for use and management of residual matter produced by agroindustry has been increasing over the years. This use has been increased, intending to improve sustainable development and reduce associated environmental problems (Badel et al., 2011; Özcan and Öner, 2015).

Moreover, BAC are a good source of LAB isolates capable of producing EPS, with a great range concerning the carbon source used. This diversification can affect the production of new biopolymers, with different chemical structures, composition, molecular weight, ramifications, and functional groups, which is highly associated with bioactivity (anticancer, antioxidant, antimicrobial, immunomodulators, probiotic, and prebiotic), as indicated in the literature (Wang et al., 2008; Zannini et al., 2016; Rahbar Saadat et al., 2019; Silva et al., 2019; Chaisuwan et al., 2020). Ultimately, this is another advantage of using LAB in the production of EPS due to their GRAS status. This feature facilitates the application of these biopolymers as natural and

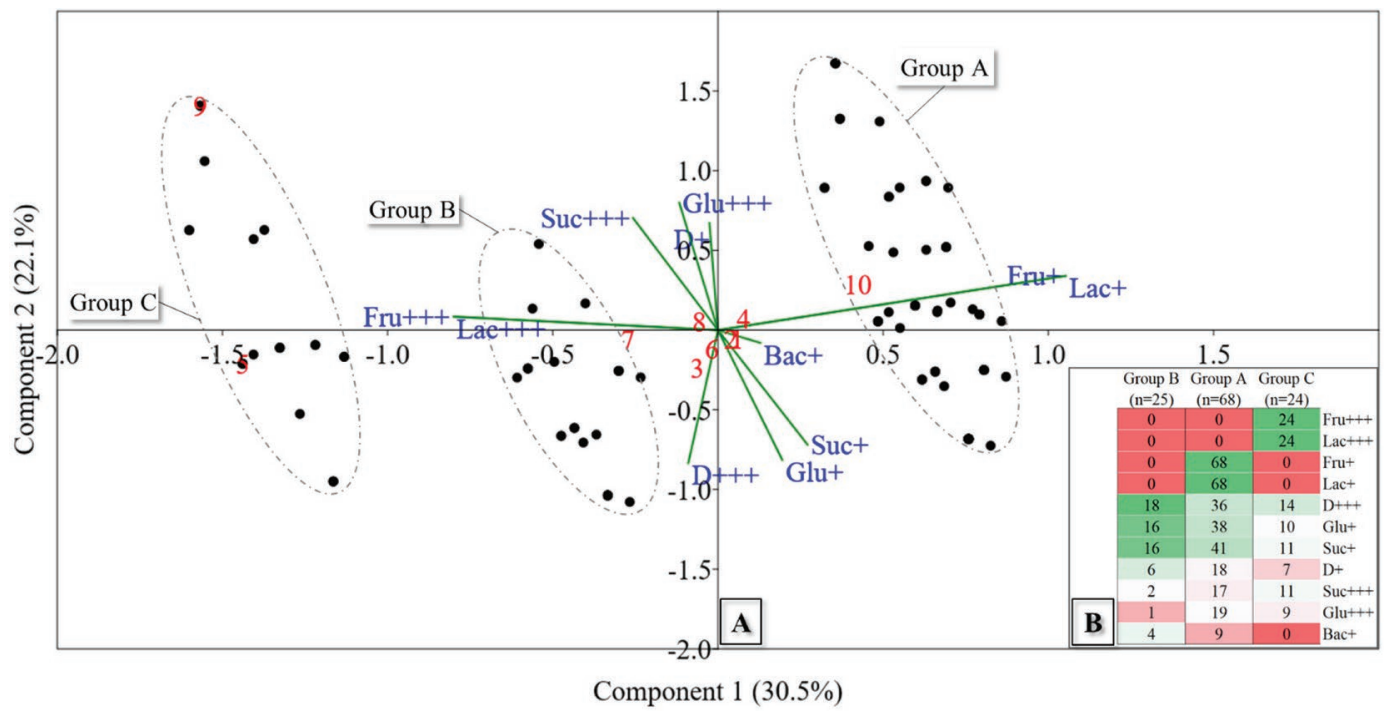

Figure 6. (A) Principal component analysis score plot of technological properties obtained from 117 lactic acid bacteria (LAB) isolates and formed groups (groups A, B, and C). (B) Resulting groups are shown according to microorganisms' phenotypic features regarding diacetyl formation (D) and exopolysaccharide production from fructose (Fru), lactose (Lac), sucrose (Suc), and glucose (Glu) as main carbon sources [both expressed as weak $(+)$ or high $(+++)$ ]. Finally, n represents the number of LAB isolates that presented the above-mentioned characteristics. 
safe food ingredients, without requiring the removal of biomass after production (Zannini et al., 2016; Silva et al., 2019). Such a concept aims to comply with the strict requirements that the legislation imposes on the addition of new additives and materials in foods.

Another vital factor to be considered is the production of active antimicrobials by LAB against pathogenic microorganisms, with emphasis on bacteriocins or bacteriocin-like substances. The lack of standardization for production of some artisanal cheeses in addition to deficiencies found during processing, such as cases of herd mastitis, poor hygiene during milking and manufacturing, and inadequacy in storage, outlet, and trading conditions, negatively affect the microbiological quality of the food product. Numerous studies reported the presence of $S$. aureus in Brazilian cheeses, with counts of up to $10^{5} \mathrm{cfu} / \mathrm{g}$, considered above the limit allowed by local legislation $\left(<10^{3} \mathrm{cfu} / \mathrm{g}\right.$; Brant et al., 2007; Zaffari et al., 2007; Kamimura et al., 2019a; Tavares et al., 2019). These figures are alarming because, at such concentrations, there might be enterotoxin formation by $S$. aureus, representing a real health risk for consumers. According to the Brazilian Ministry of Health, 2,350 cases of foodborne diseases were reported in 2018, and $S$. aureus was the third most important pathogen, responsible for $9.4 \%$ of all cases (Brazil/Ministry of Health, 2018). The high prevalence of $L$. monocytogenes (1.4-6\%) in semi-hard artisanal cheeses marketed in Brazil (Silva et al., 1998; Souza, 2002; Raimundo, 2013) is indeed worrisome for the most vulnerable population groups (expectant mothers, newborns, immunocompromised patients, and elders), for which mortality rate due to the pathogen is significantly higher $(20-30 \%$; FAO/WHO, 2004; McLauchlin et al., 2004). It is worth noting that national legislation stipulates the absence of $L$. monocytogens in dairy products.

Against this backdrop, the current study demonstrated a high number of LAB isolates (93.36\%) with antagonistic activity against $L$. monocytogenes and $S$. aureus, indicating a great antimicrobial potential of the tested LAB. This antagonistic effect was not very related to the production of bacteriocins because only 27 out of the 220 strains showed positive results in the production of compounds with proteinaceous nature. Thus, these findings are in agreement with those reported by other authors, who also attested that after neutralizing the $\mathrm{pH}$ of LAB supernatant, there was an absence or reduction in the inhibitory activity against indicator pathogens (Pisano et al., 2014; dos Santos et al., 2015; Sornplang and Piyadeatsoontorn, 2016; Ołdak et al., 2017; Partovi et al., 2019). Such behavior can be explained by other mechanisms of inhibition related to LAB in addition to bacteriocin production, such as competition for substrates and decreased $\mathrm{pH}$ levels by organic acid production (e.g., lactic, formic, propionic, and acetic acids; Favaro et al., 2015; Ołdak et al., 2019). So, these data demonstrate that antagonistic activity shown against the indicator pathogens allows the application of studied LAB isolates as biopreservatives in the production of dairy foods, increasing their shelf life.

The proteinaceous nature of the antimicrobial compounds (bacteriocin or bacteriocin-like substances) was confirmed for 27 isolates, with a variable inhibition spectrum. As the main highlights, isolates 1QB314, 2QB502, 1QB77, 3QB167, 1QB167, 1QB459, identified as Lb. plantarum, Pd. acidilactici, Lc. lactis, and Lactobacillus sp. (see Table 2) were able to inhibit at least 3 out of the 4 pathogenic strains tested. Bacteriocins production by LAB is particularly well known in traditional dairy and nondairy foods. In parallel, increasing interest in researchers and food industries for the finding of new types of biopreservative agents, especially those considered more natural and that also have geographical features, have been observed (Vélez et al., 2007; dos Santos et al., 2015; Cabral et al., 2016; Handa and Sharma, 2016; N'tcha et al., 2016; de Souza and Dias, 2017; Agostini et al., 2018; Samedi and Linton Charles, 2019). In our study, Minas artisanal, Coalho, and Caipira cheeses (Table 2) stood out as good sources of bacteriocin-producing LAB, which could be possibly used in the formulation of food products and thus contribute to increase their microbiological safety and maintain the terroir status of these artisanal products (Campagnollo et al., 2018a). Moreover, the ability to produce bacteriocins or bacteriocin-like substances against foodborne pathogens has also been considered an essential criterium for the selection of potentially probiotic LAB. For the selection of probiotic LAB, candidate strains must be carefully evaluated regarding, among other factors, biosafety to guarantee consumers will not be exposed to risks after their ingestion.

Evaluation of hemolysin presence (enzymes that cause erythrocytes lysis) and resistance to clinically used antibiotics are some of the virulence factors that need to be addressed for LAB application as biopreservatives or probiotics in foods, ensuring safety for human consumption. In this study, a high resistance rate of LAB against gentamicin, vancomycin, ciprofloxacin, and streptomycin was observed, which is in agreement with results obtained by other researches that also evaluated LAB obtained from artisanal products (Rodríguez-Alonso et al., 2009; Costa et al., 2013; Andrade et al., 2014; Agostini et al., 2018). Resistance against the antibiotics mentioned above, which belong to groups aminoglycosides (gentamicin and streptomycin), quinolones (ciprofloxacin), and glycopeptides (vancomycin), is considered natural or intrinsic for the genus Lactobacillus, although there is no risk for trans- 
fer of such resistance genes to other bacteria (Charteris et al., 1998; Danielsen and Wind, 2003; Herreros et al., 2005). The variable resistance to oxacillin ( $\beta$-lactam) observed in the present study for LAB isolates (40.9\%) does not represent a hazard itself because it has been extensively reported as an intrinsic feature for Lactobacillus sp. and is not related to plasmid transfer by conjugation (Sant'Anna et al., 2017). This resistance phenomenon can be related to the waterproof bacteria cell wall, or the production and action of $\beta$-lactamases (Charteris et al., 1998; Costa et al., 2013). These data suggest LAB isolates obtained in our work could help to restore the natural balance of intestinal microbiota in patients treated with these antibiotics.

Conversely, the highest rates of LAB isolates presenting high or moderate sensitivity against antibiotics tested were observed for tetracycline, erythromycin, and ceftazidime $(>80.5 \%)$, followed by clindamycin (from 71.8 to $76.4 \%$ ), which is a desirable finding because resistance against these antimicrobials has been associated with horizontal gene transfer (Testore et al., 2002; Gevers et al., 2003). The main reason for the emergence of multiresistant bacteria is the indiscriminate use of antibiotics as growth promoters in livestock and for the treatment of diseases; in addition to that, the food chain is known as the main route of their transmission to humans (Reis et al., 2016). Thus, susceptibility to antibiotics due to the transfer of resistance genes is a pivotal issue in candidate strains for use as probiotics or starters; otherwise, the microorganisms would act as reservoirs of these genes and transfer them to other bacteria in the host gastrointestinal tract (Handa and Sharma, 2016).

In this regard, only LAB isolates $(117 / 220)$ resistant to less than 4 antibiotics and with no risks of antibioticresistant genes transfer to other microorganisms were used for PCA. The results obtained from diacetyl, EPS, and bacteriocin assays were used as input values to run a PCA (Figure 6). The first (component 1) and the second (component 2) principal components were able to explain $30.5 \%$ and $22.1 \%$, accounting for $52.6 \%$ of the total variance. The LAB strains were distributed in the factorial space and divided into 3 groups, labeled group A, group B, and group C. These 3 distinct groups were demonstrated according to the ability of LAB isolates (1) to use lactose and fructose and lead to low [Figure 6A (group A)] or high [Figure 6A (group C)] EPS production, indicated by the development of slimy and mucoid colonies (Figure 2B); (2) to form diacetyl from lactose; and (3) to produce bacteriocins or bacteriocinlike substances [Figure 6A (group B)]. High intraspecies variability was observed, indicating the influence of isolation source on the performance of LAB isolates. This tool was indeed useful for a rational selection of autochthonous LAB from artisanal cheeses obtained in different regions of Brazil, which were shown to present a high potential for use as adjunct cultures. These adjunct cultures would have the capability to improve texture, aroma, flavor, and viscosity parameters of fermented foods (inherent characteristics of cheese type from which they were isolated). In addition, these LAB strains also act as biopreservatives depending on industries' needs, especially for small manufacturers.

\section{CONCLUSIONS}

Data obtained in this study corroborate the potential of the Brazilian market for the application of endogenous LAB from local food products, as opposed to the current use of starter cultures commercialized by foreign companies (Cabral et al., 2016), boosting the formulation of products with organoleptic characteristics similar to those from where microorganisms were obtained. Thus, by the use of multivariate statistical tools, it was possible to select 117 out of $220 \mathrm{LAB}$ isolates studied here. These isolates stood out due to the absence of hemolytic activity and their intrinsic resistance to a maximum of 4 different antibiotics, being considered as good candidates to enhance the development of adjunct cultures with balanced properties for the production of low-cost, high-quality, safe, and value-added Brazilian functional dairy products. The isolates considered as unsafe for food applications showed resistance to antimicrobials generally associated with horizontal gene transfer between bacteria, which may explain the association between specific resistance to these antibiotics and the origin of isolation. Finally, the present study is of particular importance because it is the first one to perform technological bioprospecting of microbiota from a wide variety of BAC traded in 4 main regions of the country, evidencing the high intraspecies variability in data presented, which is strongly related to the origin of isolation as demonstrated by the use of multivariate analysis.

\section{ACKNOWLEDGMENTS}

The authors acknowledge Fundação de Amparo à Pesquisa do Estado de São Paulo (FAPESP; Brazil) for financial support (Grants \#2015/25641-4, \#2017/03899-5, and \#2020/06519-1), Conselho Nacional de Desenvolvimento Científico e Tecnológico (CNPq, Grants \#403865/2013-1, \#302763/2014-7, and \#305804/2017-0; Brazil). This study was financed, in part, by the Coordenação de Aperfeiçoamento de Pessoal de Nível Superior-Brasil (CAPES)-Finance Code 001. The authors have not stated any conflicts of interest. 


\section{REFERENCES}

Agostini, C., C. Eckert, A. Vincenzi, B. L. Machado, B. C. Jordon, J. P. Kipper, A. Dullius, C. H. Dullius, D. N. Lehn, R. A. Sperotto, A. Pozzobon, C. E. Granada, M. J. Maciel, and C. F. Volken de Souza. 2018. Characterization of technological and probiotic properties of indigenous Lactobacillus spp. from south Brazil. 3 Biotech 8:1-12. https://doi.org/10.1007/s13205-018-1469-7.

Ambalam, P., J. Ramoliya, J. Dave, and B. Vyas. 2013. Safety assessment of potential probiotic strains Lactobacillus rhamnosus 231 and Lactobacillus rhamnosus V92 in mouse model. Int. J. Bioassays 2:333-337. https://doi.org/10.21746/ijbio.2013.01.0020.

Andrade, C. R. G., M. R. Souza, C. F. A. M. Penna, L. B. Acurcio, F. M. Sant'Anna, R. D. Castro, and D. L. S. Oliveira. 2014. Propriedades probióticas in vitro de Lactobacillus spp. isolados de queijos minas artesanais da Serra da Canastra - MG. Arq. Bras. Med. Vet. Zootec. 66:1592-1600. https://doi.org/10.1590/1678-6781.

Ayyash, M., B. Abu-Jdayil, F. Hamed, and R. Shaker. 2018. Rheological, textural, microstructural and sensory impact of exopolysaccharide-producing Lactobacillus plantarum isolated from camel milk on low-fat akawi cheese. Lebensm. Wiss. Technol. 87:423-431. https://doi.org/10.1016/j.lwt.2017.09.023.

Bachtarzi, N., K. Kharroub, and P. Ruas-Madiedo. 2019. Exopolysaccharide-producing lactic acid bacteria isolated from traditional Algerian dairy products and their application for skim-milk fermentations. LWT 107:117-124. https://doi.org/10.1016/j.lwt.2019 .03 .005 .

Badel, S., T. Bernardi, and P. Michaud. 2011. New perspectives for lactobacilli exopolysaccharides. Biotechnol. Adv. 29:54-66. https:/ /doi.org/10.1016/j.biotechadv.2010.08.011.

Barcelos, M. C. S., K. A. C. Vespermann, F. M. Pelissari, and G. Molina. 2020. Current status of biotechnological production and applications of microbial exopolysaccharides. Crit. Rev. Food Sci. Nutr. 60:1475-1495. https://doi.org/10.1080/10408398.2019.1575791.

Bennama, R., M. Fernández, V. Ladero, M. A. Alvarez, N. RechidiSidhoum, and A. Bensoltane. 2012. Isolation of an exopolysaccharide-producing Streptococcus thermophilus from Algerian raw cow milk. Eur. Food Res. Technol. 234:119-125. https://doi.org/ 10.1007/s00217-011-1620-8.

Berthold-Pluta, A. M., A. S. Pluta, M. Garbowska, and L. StasiakRóżańska. 2019. Exopolysaccharide-producing lactic acid bacteria - Health-promoting properties and application in the dairy industry. Adv. Microbiol. 58:191-204. https://doi.org/10.21307/PM $-2019.58 .2 .191$.

Bintsis, T. 2018. Lactic acid bacteria as starter cultures: An update in their metabolism and genetics. AIMS Microbiol. 4:665-684. https: //doi.org/10.3934/microbiol.2018.4.665.

Bozoudi, D., C. Kotzamanidis, M. Hatzikamari, N. Tzanetakis, G. Menexes, and E. Litopoulou-Tzanetaki. 2015. A comparison for acid production, proteolysis, autolysis and inhibitory properties of lactic acid bacteria from fresh and mature Feta PDO Greek cheese, made at three different mountainous areas. Int. J. Food Microbiol. 200:87-96. https://doi.org/10.1016/j.ijfoodmicro.2015.02.008.

Brant, L. M. F., L. M. Fonseca, and M. C. C. Silva. 2007. Avaliação da qualidade microbiológica do queijo-de-minas artesanal do SerroMG. Arq. Bras. Med. Vet. Zootec. 59:1570-1574. https://doi.org/ 10.1590/S0102-09352007000600033.

Brazil/Ministry of Health. 2018. Outbreaks of Foodborne Diseases in Brazil. Accessed Nov. 11, 2019. https://portalarquivos2.saude.gov .br/images/pdf/2018/janeiro/17/Apresentacao-Surtos-DTA-2018 .pdf.

Cabral, M. L. B., M. dos S. F. de Lima, G. A. de A. Fernandes, E. F. da Costa, A. L. F. Porto, and M. T. H. Cavalcanti. 2016. Queijos artesanais: Fonte de bactérias ácido láticas selvagens para formulação de fermentos tradicionais. J. Bioenergy Food Sci. 3:207-215. https://doi.org/10.18067/jbfs.v3i4.111.

Campagnollo, F. B., U. Gonzales-Barron, V. A. Pilão Cadavez, A. S. Sant'Ana, and D. W. Schaffner. 2018a. Quantitative risk assessment of Listeria monocytogenes in traditional Minas cheeses: The cases of artisanal semi-hard and fresh soft cheeses. Food Control 92:370-379. https://doi.org/10.1016/j.foodcont.2018.05.019.
Campagnollo, F. B., L. P. Margalho, B. A. Kamimura, M. D. Feliciano, L. Freire, L. S. Lopes, V. O. Alvarenga, V. A. P. Cadavez, U. Gonzales-Barron, D. W. Schaffner, and A. S. Sant'Ana. 2018b. Selection of indigenous lactic acid bacteria presenting anti-listerial activity, and their role in reducing the maturation period and assuring the safety of traditional Brazilian cheeses. Food Microbiol. 73:288-297. https://doi.org/10.1016/j.fm.2018.02.006.

Chaisuwan, W., K. Jantanasakulwong, S. Wangtueai, Y. Phimolsiripol, T. Chaiyaso, C. Techapun, S. Phongthai, S. G. You, J. M. Regenstein, and P. Seesuriyachan. 2020. Microbial exopolysaccharides for immune enhancement: Fermentation, modifications and bioactivities. Food Biosci. 35:100564. https://doi.org/10.1016/j .fbio.2020.100564.

Charteris, W. P., H. P. M. Kelly, L. Morelli, and J. K. Collins. 1998. Antibiotic susceptibility of potentially probiotic Lactobacillus species. J. Food Prot. 61:1636-1643. https://doi.org/10.4315/0362 $-028 \mathrm{X}-61.12 .1636$

Clark, S., and C. K. Winter. 2015. Diacetyl in foods: A review of safety and sensory characteristics. Compr. Rev. Food Sci. Food Saf. 14:634-643. https://doi.org/10.1111/1541-4337.12150.

CLSI. 2012. Performance Standards for Antimicrobial Susceptibility Testing; Twenty-Second Informational Supplement. CLSI document M100-S22. Clinical and Laboratory Standards Institute, Wayne, PA.

Colombo, M., S. D. Todorov, M. Eller, and L. A. Nero. 2018. The potential use of probiotic and beneficial bacteria in the Brazilian dairy industry. J. Dairy Res. 85:487-496. https://doi.org/10.1017/ S0022029918000845.

Costa, H. H. S., M. R. Souza, L. B. Acúrcio, A. F. Cunha, M. F. S. Resende, and Á. C. Nunes. 2013. In vitro probiotic potential of lactic acid bacteria isolated from artisanal minas cheese from Serra da Canastra, MG. Arq. Bras. Med. Vet. Zootec. 65:1858-1866. https: //doi.org/10.1590/S0102-09352013000600038.

Cuffia, F., C. V. Bergamini, É. R. Hynes, I. V. Wolf, and M. C. Perotti. 2020. Evaluation of autochthonous cultures to improve the cheese flavor: A case study in hard cheese model. Food Sci. Technol. Int. 26:173-184. https://doi.org/10.1177/1082013219881512.

Danielsen, M., and A. Wind. 2003. Susceptibility of Lactobacillus spp. to antimicrobial agents. Int. J. Food Microbiol. 82:1-11. https:// doi.org/10.1016/S0168-1605(02)00254-4.

de Almeida Júnior, W. L. G., Í. S. Ferrari, J. V. de Souza, C. D. A. da Silva, M. M. da Costa, and F. S. Dias. 2015. Characterization and evaluation of lactic acid bacteria isolated from goat milk. Food Control 53:96-103. https://doi.org/10.1016/j.foodcont.2015 .01 .013 .

De Pasquale, I., R. Di Cagno, S. Buchin, M. De Angelis, and M. Gobbetti. 2019. Use of autochthonous mesophilic lactic acid bacteria as starter cultures for making Pecorino Crotonese cheese: Effect on compositional, microbiological and biochemical attributes. Food Res. Int. 116:1344-1356. https://doi.org/10.1016/j.foodres.2018.10 .024 .

de Souza, J. V., and F. S. Dias. 2017. Protective, technological, and functional properties of select autochthonous lactic acid bacteria from goat dairy products. Curr. Opin. Food Sci. 13:1-9. https:// doi.org/10.1016/j.cofs.2017.01.003.

dos Santos, K. M. O., A. D. S. Vieira, F. C. A. Buriti, J. C. F. do Nascimento, M. E. S. de Melo, L. M. Bruno, M. de Fátima Borges, C. R. C. Rocha, A. C. de Souza Lopes, B. D. G. de Melo Franco, and S. D. Todorov. 2015. Artisanal Coalho cheeses as source of beneficial Lactobacillus plantarum and Lactobacillus rhamnosus strains. Dairy Sci. Technol. 95:209-230. https://doi.org/10.1007/ s13594-014-0201-6.

Duboc, P., and B. Mollet. 2001. Applications of exopolysaccharides in the dairy industry. Int. Dairy J. 11:759-768. https://doi.org/10 .1016/S0958-6946(01)00119-4.

FAO/WHO (Food and Agriculture Organization/World Health Organization). 2004. Risk assessment of Listeria monocytogenes in ready-to-eat foods: Technical report. Microbiological Risk Assessment Series, no. 5. Accessed Feb. 3, 2020. http://www.fao.org/3/ a-y5394e.pdf. 
Favaro, L., A. L. Barretto Penna, and S. D. Todorov. 2015. Bacteriocinogenic LAB from cheeses - Application in biopreservation? Trends Food Sci. Technol. 41:37-48. https://doi.org/10.1016/j.tifs .2014.09.001.

Ferrari, I. da S., J. V. de Souza, C. L. Ramos, M. M. da Costa, R. F. Schwan, and F. S. Dias. 2016. Selection of autochthonous lactic acid bacteria from goat dairies and their addition to evaluate the inhibition of Salmonella typhi in artisanal cheese. Food Microbiol. 60:29-38. https://doi.org/10.1016/j.fm.2016.06.014.

Gevers, D., M. Danielsen, G. Huys, and J. Swings. 2003. Molecular characterization of tet $(\mathrm{M})$ genes in Lactobacillus isolates from different types of fermented dry sausage. Appl. Environ. Microbiol. 69:1270-1275. https://doi.org/10.1128/AEM.69.2.1270-1275.2003.

Giraffa, G. 2012. Selection and design of lactic acid bacteria probiotic cultures. Eng. Life Sci. 12:391-398. https://doi.org/10.1002/elsc 201100118.

Guo, X. H., J. M. Kim, H. M. Nam, S. Y. Park, and J. M. Kim. 2010. Screening lactic acid bacteria from swine origins for multistrain probiotics based on in vitro functional properties. Anaerobe 16:321-326. https://doi.org/10.1016/j.anaerobe.2010.03.006.

Hammer, Ø., D. A. T. Harper, and P. D. Ryan. 2001. PAST: Paleontological Statistics software package for education and data analysis. Palaeontol. Electronica 4:4.

Handa, S., and N. Sharma. 2016. In vitro study of probiotic properties of Lactobacillus plantarum F22 isolated from chhang - A traditional fermented beverage of Himachal Pradesh, India. J. Genet. Eng. Biotechnol. 14:91-97. https://doi.org/10.1016/j.jgeb.2016.08.001.

Harris, L. J., M. A. Daeschel, M. E. Stiles, and T. R. Klaenhammer. 1989. Antimicrobial activity of lactic acid bacteria against Listeria monocytogenes. Food Biosci. 52:384-387. https://doi.org/10.4315/ 0362-028X-52.6.384.

Herreros, M. A., H. Sandoval, L. González, J. M. Castro, J. M. Fresno, and M. E. Tornadijo. 2005. Antimicrobial activity and antibiotic resistance of lactic acid bacteria isolated from Armada cheese (a Spanish goats' milk cheese). Food Microbiol. 22:455-459. https:// doi.org/10.1016/j.fm.2004.11.007.

Ishola, R. O., and B. C. Adebayo-Tayo. 2012. Screening of lactic acid bacteria isolated from fermented food for bio-molecules production. AU J. Technol. 15:205-217.

Jaouani, I., M. S. Abbassi, S. C. Ribeiro, M. Khemiri, R. Mansouri, L. Messadi, and C. C. G. Silva. 2015. Safety and technological properties of bacteriocinogenic enterococci isolates from Tunisia. J. Appl. Microbiol. 119:1089-1100. https://doi.org/10.1111/jam .12916 .

Joković, N., J. Rajković, K. Veljović, M. Tolina, and L. Topisirović. 2014. Screening of lactic acid bacteria isolated from Serbian kajmak for use in starter cultures. Biol. Nyssana 5:37-46.

Kamimura, B., M. Magnani, W. A. Luciano, F. B. Campagnollo, T. C. Pimentel, V. O. Alvarenga, B. O. Pelegrino, A. G. Cruz, and A. S. Sant'Ana. 2019a. Brazilian artisanal cheeses: An overview of their characteristics, main types and regulatory aspects. Compr. Rev. Food Sci. Food Saf. 18:1636-22. https://doi.org/10.1111/ 1541-4337.12486.

Kamimura, B. A., F. De Filippis, A. S. Sant'Ana, and D. Ercolini. 2019b. Large-scale mapping of microbial diversity in artisanal Brazilian cheeses. Food Microbiol. 80:40-49. https://doi.org/10.1016/ j.fm.2018.12.014.

Kanimozhi, J., V. Sivasubramanian, A. Achary, M. Vasanthi, S. P. Vinson, and R. Sivashankar. 2018. Bioprocessing of agrofood industrial wastes for the production of bacterial exopolysaccharide. Pages 67-98 in Bioprocess Engineering for a Green Environment. V. Sivasub, ed. CRC Press, Boca Raton, FL.

King, N. 1948. Modification of Voges-Proskauer test for rapid colorimetric determination of acetyl methyl carbimol plus diacetyl in butter. J. Dairy Sci. 13:860-866. https://doi.org/10.3168/jds .S0022-0302(57)94694-5.

Klūga, A., M. Terentjeva, A. Kántor, M. Kluz, C. Puchalski, and M. Kačániová. 2017. Antibacterial Activity of Melissa officinalis L., Mentha piperita L., Origanum vulgare L. and Malva mauritiana against bacterial microflora isolated from fish. Adv. Res. Life Sci. 1:75-80. https://doi.org/10.1515/arls-2017-0013.
Li, X., A. Duerkop, and O. S. Wolfbeis. 2009. A fluorescent probe for diacetyl detection. J. Fluoresc. 19:601-606. https://doi.org/10 .1007/s10895-008-0450-y.

Lynch, K. M., E. Zannini, A. Coffey, and E. K. Arendt. 2018. Lactic acid bacteria exopolysaccharides in foods and beverages: Isolation, properties, characterization, and health benefits. Annu. Rev. Food Sci. Technol. 9:155-176. https://doi.org/10.1146/annurev-food -030117-012537.

Malik, A., M. Radji, S. Kralj, and L. Dijkhuizen. 2009. Screening of lactic acid bacteria from Indonesia reveals glucansucrase and fructansucrase genes in two different Weissella confusa strains from soya. FEMS Microbiol. Lett. 300:131-138. https://doi.org/10 $.1111 /$ j.1574-6968.2009.01772.x.

Margalho, L. P. 2020. Bioprospection of technological, probiotic potential and safety assessment of endogenous lactic acid bacteria isolated from Brazilian artisanal cheeses. PhD thesis, Department of Food Science, University of Campinas, São Paulo, Brazil.

McLauchlin, J., R. T. Mitchell, W. J. Smerdon, and K. Jewell. 2004. Listeria monocytogenes and listeriosis: A review of hazard characterization for use in microbiological risk assessment of foods. Int. J. Food Microbiol. 92:15-33. https://doi.org/10.1016/S0168 -1605(03)00326-X.

N’tcha, C., S. Haziz, P. Agbobatinkpo, G. Vieira-Dalodé, B. Boya, J. T. Claude Codjia, P. A. Kayodé, and L. Baba-Moussa. 2016. Probiotic properties of lactic acid bacteria isolated from a Beninese traditional Beer's ferment. Int. J. Appl. Biol. Pharm. Technol. 7:314-330

Ołdak, A., D. Zielińska, A. Łepecka, E. Długosz, and D. KołożynKrajewska. 2019. Lactobacillus plantarum strains isolated from Polish regional cheeses exhibit anti-staphylococcal activity and selected probiotic properties. Probiotics Antimicrob. Proteins 2019:1-14. https://doi.org/10.1007/s12602-019-09587-w.

Ołdak, A., D. Zielińska, A. Rzepkowska, and D. Kołozyn-Krajewska. 2017. Comparison of antibacterial activity of Lactobacillus plantarum strains isolated from two different kinds of regional cheeses from Poland: Oscypek and Korycinski cheese. BioMed Res. Int. 2017:6820369. https://doi.org/10.1155/2017/6820369.

Oleksy, M., and E. Klewicka. 2018. Exopolysaccharides produced by Lactobacillus sp.: Biosynthesis and applications. Crit. Rev. Food Sci. Nutr. 58:450-462. https://doi.org/10.1080/10408398.2016 .1187112 .

Özcan, E., and E. T. Öner. 2015. Microbial production of extracellular polysaccharides from biomass sources. Pages 161-184 in Polysaccharides - Bioactivity and Biotechnology. J.-M. Ramawat, Kishan Gopal, and Mérillon, ed. Springer International Publishing, Cham, Switzerland.

Partovi, R., H. Gandomi, and A. Akhondzadeh Basti. 2019. Safety aspects of Lactobacillus plantarum strains isolated from siahmazgi cheese. Ankara Univ. Vet. Fak. Derg. 66:337-342. https://doi.org/ 10.33988/auvfd.502784.

Paulo, E. M., M. P. Vasconcelos, I. S. Oliveira, H. M. J. Affe, R. Nascimento, I. S. Melo, M. R. A. Roque, and S. A. Assis. 2012. An alternative method for screening lactic acid bacteria for the production of exopolysaccharides with rapid confirmation. Cienc. Technol. Aliment. 32:710-714. https://doi.org/10.1590/S0101 -20612012005000094 .

Peivasteh-Roudsari, L., M. Pirhadi, H. Karami, B. Tajdar-oranj, E. Molaee-Aghaee, and P. Sadighara. 2019. Probiotics and food safety: An evidence-based review. J. Food Saf. Hyg. 5:1-9.

Pereira, G. V. D. M., D. P. D. C. Neto, A. C. D. O. Junqueira, S. G. Karp, L. A. J. Letti, A. I. M. Júnior, and C. R. Soccol. 2019. A review of selection criteria for starter culture development in the food fermentation industry. Food Rev. Int. 0:1-33. https://doi .org/10.1080/87559129.2019.1630636.

Pisano, M. B., S. Viale, S. Conti, M. E. Fadda, M. Deplano, M. P. Melis, M. Deiana, and S. Cosentino. 2014. Preliminary evaluation of probiotic properties of Lactobacillus strains isolated from Sardinian dairy products. BioMed Res. Int. 2014:286390. https://doi .org/10.1155/2014/286390. 
Pradhan, D., R. H. Mallappa, and S. Grover. 2020. Comprehensive approaches for assessing the safety of probiotic bacteria. Food Control 108:106872. https://doi.org/10.1016/j.foodcont.2019.106872.

Rahbar Saadat, Y., A. Yari Khosroushahi, and B. Pourghassem Gargari. 2019. A comprehensive review of anticancer, immunomodulatory and health beneficial effects of the lactic acid bacteria exopolysaccharides. Carbohydr. Polym. 217:79-89. https://doi.org/10 .1016/j.carbpol.2019.04.025.

Raimundo, D. C. 2013. Listeria monocytogenes em queijo minas meia cura: Análise quantitativa, qualitativa e perfil molecular das cepas isoladas. PhD thesis, School of Veterinary Medicine and Animal Science (FMVZ) of University of São Paulo (USP), Brazil. https:/ /doi.org/10.11606/T.10.2013.tde-28062013-091254.

Reis, N. A., M. A. F. Saraiva, E. A. A. Duarte, E. A. de Carvalho, B. B. Vieira, and N. S. Evangelista-Barreto. 2016. Probiotic properties of lactic acid bacteria isolated from human milk. J. Appl. Microbiol. 121:811-820. https://doi.org/10.1111/jam.13173.

Rincon-Delgadillo, M. I., A. Lopez-Hernandez, I. Wijaya, and S. A. Rankin. 2012. Diacetyl levels and volatile profiles of commercial starter distillates and selected dairy foods. J. Dairy Sci. 95:11281139. https://doi.org/10.3168/jds.2011-4834.

Rodríguez-Alonso, P., C. Fernández-Otero, J. A. Centeno, and J. I. Garabal. 2009. Antibiotic resistance in lactic acid bacteria and micrococcaceae/staphylococcaceae isolates from artisanal raw milk cheeses, and potential implications on cheese making. J. Food Sci. 74:M284-M293. https://doi.org/10.1111/j.1750-3841.2009.01217 .x.

Sahraoui, Y., K. Fayolle, F. Leriche, A. Le Flèche-Matéos, and D. Sadoun. 2015. Antibacterial and technological properties of Lactococcus lactis ssp. lactis KJ660075 strain selected for its inhibitory power against Staphylococcus aureus for cheese quality improving. J. Food Sci. Technol. 52:7133-7142. https://doi.org/10.1007/ s13197-015-1845-9.

Samedi, L., and A. Linton Charles. 2019. Evaluation of technological and probiotic abilities of local lactic acid bacteria. J. Appl. Environ. Microbiol. 7:9-19. https://doi.org/10.12691/jaem-7-1-3.

Sanalibaba, P., and G. A. Cakmak. 2016. Exopolysaccharides production by lactic acid bacteria. Appl. Microbiol. 2:1-5. https://doi .org/10.4172/2471-9315.1000115.

Sant'Anna, F. M., L. B. Acurcio, L. B. Alvim, R. D. de Castro, L. G. de Oliveira, A. M. da Silva, Á. C. Nunes, J. R. Nicoli, and M. R. Souza. 2017. Assessment of the probiotic potential of lactic acid bacteria isolated from Minas artisanal cheese produced in the Campo das Vertentes region, Brazil. Int. J. Dairy Technol. 70:592-601. https://doi.org/10.1111/1471-0307.12422.

Schmid, J., V. Sieber, and B. Rehm. 2015. Bacterial exopolysaccharides: Biosynthesis pathways and engineering strategies. Front. Microbiol. 6:496. https://doi.org/10.3389/fmicb.2015.00496.

Silva, M. C., E. Hofer, and A. Tibana. 1998. Incidence of Listeria monocytogenes in cheese produced in Rio de Janeiro, Brazil. J. Food Prot. 61:354-356. https://doi.org/10.4315/0362-028x-61.3 .354 .

Silva, L. A., J. H. P. Lopes Neto, and H. R. Cardarelli. 2019. Exopolysaccharides produced by Lactobacillus plantarum: Technological properties, biological activity, and potential application in the food industry. Ann. Microbiol. 69:321-328. https://doi.org/10 .1007/s13213-019-01456-9.

Skariyachan, S., and S. Govindarajan. 2019. Biopreservation potential of antimicrobial protein producing Pediococcus spp. towards selected food samples in comparison with chemical preservatives. Int. J. Food Microbiol. 291:189-196. https://doi.org/10.1016/j .ijfoodmicro.2018.12.002.

Sornplang, P., and S. Piyadeatsoontorn. 2016. Probiotic isolates from unconventional sources: A review. J. Anim. Sci. Technol. 58:26. https://doi.org/10.1186/s40781-016-0108-2.

Souza, R. A. 2002. Incidência de Listeria monocytogenes em Queijo tipo Coalho artesanal comercializado a temperatura ambiente em Fortaleza. Master's thesis, Department of Food Technology, Federal University of Ceará, Brazil.
Taboada, N., M. Núñez, R. Medina, and M. S. López Alzogaray. 2014 Characterization and technological properties of lactic acid bacteria isolated from traditional Argentinean goat's milk products. Food Biotechnol. 28:123-141. https://doi.org/10.1080/08905436 .2014.895944.

Tavares, A. B., E. A. N. L. D. Cavalcanti, C. D. Timm, H. G. de Lima, and N. D. Cereser. 2019. Queijo Artesanal Produzido No Sul Do Rio Grande Do Sul: Avaliação Físico-Química, Microbiológica E Suscetibilidade a Antimicrobianos De Isolados De Staphylococcus Coagulase Positiva. Cienc. Anim. Bras. 20:e47184. https://doi .org/10.1590/1089-6891v20e-47184.

Testore, G. P., C. Sarrecchia, E. Zupi, P. Sordillo, E. Valli, F. Bove, and M. Andreoni. 2002. Antibiotic susceptibility of lactobacilli isolated from the cervix of healthy women. Microb. Ecol. Health Dis. 14:14-18. https://doi.org/10.1080/089106002760002702.

Todorov, S. D. 2019. What bacteriocinogenic lactic acid bacteria do in the milk? Pages 149-174 in Raw Milk - Balance Between Hazards and Benefits. A. G. Wolff, ed. Academic Press, London, UK.

van Reenen, C. A., Dicks, and Chikindas.. 1998. Isolation, purification and partial characterization of plantaricin 423, a bacteriocin produced by Lactobacillus plantarum. J. Appl. Microbiol. 84:11311137. https://doi.org/10.1046/j.1365-2672.1998.00451.x.

Vélez, M. P., K. Hermans, T. L. A. Verhoeven, S. E. Lebeer, J. Vanderleyden, and S. C. J. De Keersmaecker. 2007. Identification and characterization of starter lactic acid bacteria and probiotics from Columbian dairy products. J. Appl. Microbiol. 103:666-674. https: //doi.org/10.1111/j.1365-2672.2007.03294.x.

Wang, J., X. Fang, T. Wu, W. Min, and Z. Yang. 2018. Exopolysaccharide producing Lactobacillus plantarum SKT109 as adjunct culture in Cheddar cheese production. Lebensm. Wiss. Technol. 97:419-426. https://doi.org/10.1016/j.lwt.2018.07.011.

Wang, P. G., H. Guo, W. Yi, and J. K. Song. 2008. Current understanding on biosynthesis of microbial polysaccharides. Curr. Top. Med. Chem. 8:141-151. https://doi.org/10.2174/156802608783378873.

Yuksekdag, Z. N., and B. Aslim. 2008. Influence of different carbon sources on exopolysaccharide production by Lactobacillus delbrueckii ssp. bulgaricus (B3, G12) and Streptococcus thermophilus (W22). Braz. Arch. Biol. Technol. 51:581-585. https://doi.org/10 .1590/S1516-89132008000300019.

Zaffari, C. B., J. F. Mello, and M. da Costa. 2007. Qualidade bacteriológica de queijos artesanais comercializados em estradas do litoral norte do Rio Grande do Sul, Brasil. Cienc. Rural 37:862-867. https://doi.org/10.1590/S0103-84782007000300040.

Zannini, E., D. M. Waters, A. Coffey, and E. K. Arendt. 2016. Production, properties, and industrial food application of lactic acid bacteria-derived exopolysaccharides. Appl. Microbiol. Biotechnol. 100:1121-1135. https://doi.org/10.1007/s00253-015-7172-2.

Zeidan, A. A., V. K. Poulsen, T. Janzen, P. Buldo, P. M. F. Derkx, G. Øregaard, and A. R. Neves. 2017. Polysaccharide production by lactic acid bacteria: From genes to industrial applications. FEMS Microbiol. Rev. 41(Supp_1):S168-S200. https://doi.org/10.1093/ femsre/fux017.

Zhang, L., X. Li, H. Ren, L. Liu, L. Ma, M. Li, and W. Bi. 2015. Impact of using exopolysaccharides (EPS)-producing strain on qualities of half-fat cheddar cheese. Int. J. Food Prop. 18:1546-1559. https://doi.org/10.1080/10942912.2014.921198.

\section{ORCIDS}

Larissa P. Margalho () https://orcid.org/0000-0002-4303-3705 Marcelo D'Elia Feliciano ๑ https://orcid.org/0000-0002-3245-9743 Christian E. Silva (® https://orcid.org/0000-0003-2914-6196 Júlia S. Abreu ๑ https://orcid.org/0000-0001-5023-2692 Marcos Vinícius Fiorentini Piran @ https://orcid.org/0000-0002-4011 $-7567$

Anderson S. Sant'Ana (i) https://orcid.org/0000-0001-5052-2315 